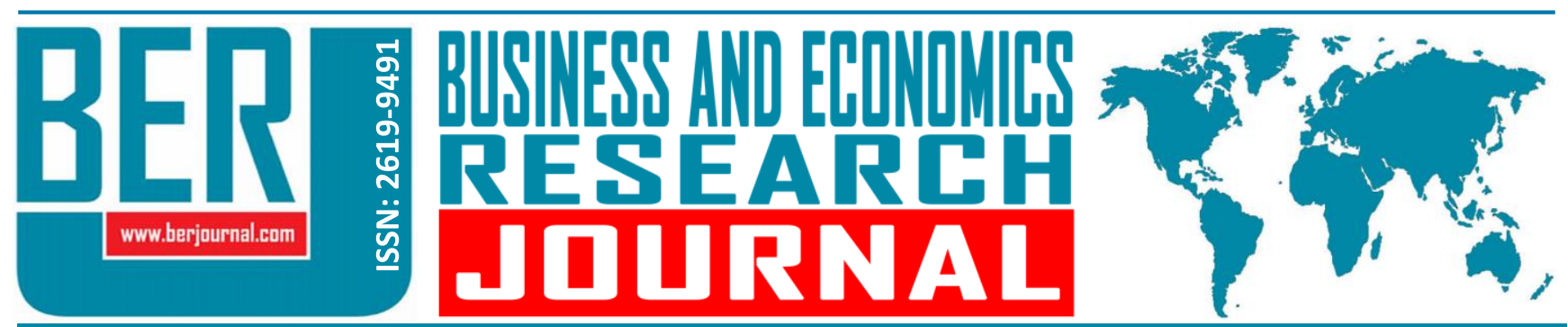

Business and Economics Research Journal Vol. 10, No. 5, 2019, pp. 1051-1070 doi: 10.20409/berj.2019.221

\section{Gelişmiş ve Gelişmekte Olan Ülkelerde İktisadi Büyüme, Kamu Gelirleri ve Harcamalarının Çift Yönlü Nedenselliğine Dair Ampirik Bir Analiz ${ }^{1}$}

\section{S. Cagri Esener}

Öz: Bu çalışmanın temel amacı kamu gelirleri, hükümet harcamaları ile iktisadi büyüme değerleri arasındaki ilişkinin uzun dönemli bir analizle tespitidir. Söz konusu analizlerde; Wagner Yasası, Peacock-Wiseman Sıçrama Tezi ve maliye politikasına Klasik ve Keynesyen bakış da hesaba katılmıştır. Çalışmada değişkenlerin analizi için panel Granger nedensellik yönteminden yararlanılmış; gerek gelir ve harcamaların büyümeyle gerekse de kendi aralarındaki ve tersi yöndeki ilişkileri irdelenmiş ve farklı örnek ülkeler için farklı bağlantılara rastlanılmıştır. iktisadi aktivite açııından küreselleşme ile ön plana çıkmış gelişmekte olan ve gelişmiş 22 ülkenin ele alındığı analizlerde 1985-2017 yılları arası döneme ait veriler kullanılmıştır. Ampirik analizlerden elde edilen bulgulara göre, büyüme cephesi için; GSYiH bağımlı değişkenleriyle istatistiksel olarak daha kuvvetli etkileşim içerisinde olan bağımsız değişkenin kamu gelirleri olduğu, buna karşın, kimi ülkeler için giderlerin de belirleyici olabildiği tespit edilmiştir. Öte yandan, gelir ve harcamaların kendi arasındaki etkileşimi açııından ise dört ülkenin tek yönlü bir biçimde harcama-vergi ve bir ülkenin de çift yönlü olarak mali senkronizasyon (uyum) hipotezini desteklediği sonucuna ulaşılmıştır. Çalışma özelinde, özellikle kamu harcamalarının kamu gelirlerini; kamu gelirlerinin ve GSYiH değerlerinin de birbirlerini kuvvetli biçimde tetikleyebildiği savunulabilir.

\section{A Two-Way Empirical Investigation on Economic Growth, Public Revenue and Expenditure for Developed and Developing Countries}

\begin{abstract}
By focusing on the investigation of long-term, this study aims to examine the relationship between public revenue, government expenditure and economic growth while bearing Wagner's Law, Peacock-Wiseman's Displacement Effect, Classical and Keynesian View on fiscal policy in mind. We employed the bootstrap panel Granger causality methodology to analyze the variables and found different linkages between both revenue and spending versus gross domestic product ratios but also some relations within and vice versa. We took a sample of 22 developing and developed countries which are noticeable with their economic activities in the recent era of globalization for the period of 1985-2017. According to the empirical results, for the growth front; public revenue independent variable is much more related or integrated with the dependent GDP variables for some countries while expenditure is also important as a deterministic factor for some others. On the other hand, for the revenue and expenditure case, the results indicate an evidence of a unilateral relationship for four countries which are supporting spend-tax and one other has bidirectional interaction that associated with fiscal synchronization hypotheses. Conspicuously, triggering affection through government expenditure to revenue and a both-way interaction between public revenue to gross domestic product can be expressed.
\end{abstract}

Anahtar Sözcükler: Kamu Gelirleri ve Hükümet Harcamaları, Ekonomik Büyüme, Bootstrap Panel Granger Nedensellik, Wagner Kanunu, Sıçrama Tezi

JEL: H0O, H2O, H50, O47, C33

Geliş : 29 Mayıs 2019

Düzeltme : 20 Ağustos 2019

Kabul 04 Ekim 2019

Tür : Araştırma
Keywords: Public Revenue and Government Expenditure, Economic Growth, Bootstrap Panel Granger Causality, Wagner's Law, Displacement Effect

JEL: H00, H2O, H50, O47, C33

Received : 29 May 2019

Revised : 20 August 2019

Accepted : 04 October 2019

Type : Research 


\section{Giriş}

Kamu politikalarındaki herhangi bir değişikliğin iktisadi aktiviteyi belirli bir düzeyde etkilediği savı, gerek Ortodoks gerekse de heterodoks (veya alternatif) görüş savunucularınca uzun yıllardır tartışılagelmiştir. ${ }^{2}$ Takip eden bölümlerde de değinileceği üzere, özellikle son yarım asırlık süreçte muhtelif sayıda çalışma kamu gelirleri veya giderleri ile iktisadi gelişme arasında bu türden bir bağ bulunup bulunmadığını ampirik yöntemlerle de sınamıştır. İktisat okullarının hemen hepsince kabul gördüğü üzere, "vergiler ve harcamalar" (ya da daha geniş çapta ele alındığında maliye politikası), tıpkı para politikası araçları gibi, etkin bir biçimde kullanıldığında ekonomide güven ve pozitif ivmelenme yaratarak ülkenin gelişimini olumlu yönde etkileyebilir. Ancak burada kamu kesiminin optimum hizmet alanı ve buna bağlı olarak devletin ekonomiye müdahale sınııının ne olacağııın tespitinde, politik ve iktisadi görüş farklııklarının sürdüğünü de belirtmek gerekir. Söz konusu düşünsel farklılıklar, maliye politikası aracının seçimi yanı sıra uygulanacak politika zaman ve mekân bileşkesini de değiştirebilmektedir. Politika yapıcılarca alınacak tüm bu kararlar ise ülkenin iktisadi kalkınma düzeylerine bir noktada yansıyacaktır.

Gelişmekte olan bir ülkede çeşitli alanlarda tasarruf, sermaye ve özel sektörün yokluğu veya yetersizliği mali araçların kullanımı için temel teşkil edebilirken gelişmiş ülkelerde ise -sorunlar yapısal olmaktan çok konjonktürel olabildiği için-, aynı araçlar o sorunlu döneme has bir enstrüman olarak kullanılabilmektedir. Bu araçların para politikası araçlarına kıyasla karar alma süreçleri ve uygulanmaları kimi zaman uzayabildiği ya da gecikebildiği (buna karşın kimi iktisat okullarına göre etkileri daha güçlü olabildiği) için büyüme üzerinde pozitif veya negatif etki yaratabilecekleri varsayılmaktadır. Öte yandan, kamu gelir veya harcamalarının ekonomi üzerinde uzun dönemde etkisinin tarafsız olacağını savunan görüşler de mevcuttur.

Bugün elektrik, su, iletişim, ulaşım ve benzeri altyapı faaliyetlerinin gerçekleştirilmesinde ya da tam, yarı, özel kamusal veya erdemli mal ve hizmetlerin üretilmesinde devlet gelir ve harcamaları ya büyük oranda tek başına ya da belirli düzeylerde rol oynamaya devam etmektedir. Kurulan altyapının sürekli kılınması ve böylelikle kamuda kurumsallaşmanın yaratılması için de yine bu araçların devamlılığı şart olduğundan; bu değişkenlerin, iktisadi büyüme değerleri ile de doğrudan veya dolaylı bir ilişki olabileceğini değerlendirmek güç olmayacaktır. Ancak bu konuda yapılan ve neden-sonuç ilişkileri çerçevesinde kamu gelir ve giderlerini hem kendi aralarında hem de GSYiH ve kişi başı gelir verileriyle çift yönlü olarak analiz eden çalışma yok denecek kadar azdır.

Bu çalışmada, araştırmaya konu ülkelerin GSYiH, kamu gelir ve harcama düzeyleri arasında bir ilinti olup olmadığı sorusuna cevap aranacaktır. Eğer varsa, ülkelerce maliye politikası açısından uzun dönemde ortak bir pozisyon alınıp alınamayacağı, alınabilirse hangi aracın öncelikli olarak tercih edilmesi gerektiği tespit edilmeye çalışılacaktır. Dolayısıyla belirtilen çerçevede, toplam kamu gelir ve giderlerinin ekonomik büyüme (GSYiH ve kişi başı GSYiH) değişkenleriyle ve kendi aralarındaki üçlü nedensellik ilişkileri incelenerek OECD üyesi 22 gelişmiş ve gelişmekte olan ekonomi üzerinden uzun dönemli (1985-2017) panel veri analizleri vasıtasıyla ilişkilerin 'her bir ülke için yönü' tespit edilmeye çalışılacaktır. Aynı doğrultuda, takip eden bölüme teorik çerçeve ve ampirik literatür taraması ile başlanacak; ikinci bölümde, değişkenler, veri seti ve metodoloji tanıtılacak; üçüncü bölümde ampirik bulgular tablolar vasıtasıyla sunulup yorumlanacak; sonuç ve değerlendirme kısmıyla da çalışma nihayetlendirilecektir.

\section{Teorik Çerçeve ve Ampirik Literatür}

\subsection{Teorik Çerçeve}

Iktisadi ve mali politika açısından önceliklerin tespitinde hükümetin tercihlerini gösteren başlıca araçlar kamu gelir ve giderleridir. Sürdürülebilir büyüme ve kalkınma açısından birçok faaliyet alanı en azından bir noktada devletin sağlayacağı bu gelir ve harcama imkânlarına bağlı olarak genişleyebilmekte veya daralabilmektedir. En azından teoride, gelişmekte olan ülkelerde kamu yararını (toplumsal faydayı) maksimize edebilmek için piyasa sisteminin eksik işlediği alanlarda devletler (çeşitli destek mekanizmaları vasıtasıyla) ekonomiyi belirli bir denge noktasına yaklaştırmaya çalışmaktadır. 
Klasik dönem iktisatçılarının önemli bir kısmı yukarıda sözü edilen denge ya da denklik noktasına kadar devletlerin piyasaya gelir, harcama, borçlanma gibi enstrümanlarla müdahale edebileceği fikrini kabul etmektedirler. Adam Smith, "Ulusların Zenginliği (1776)" isimli eserinde 'laissez-faire' piyasayı arz ve talebin devlet müdahalesi olmaksızın belirli bir denkliğe ulaştığı varsayımı üzerine kurmaktadır. 1929 Büyük Buhranı sonrasında John Maynard Keynes klasik iktisadi görüş savunucularının çok uzun vadelerle ilgili olduklarını buna karşın "uzun vadede hepimizin ölmüş olacağını"3 ileri sürmüştür. Keynes'in burada vurguladığı nokta devletin kısa dönemde de elindeki araçlarla (vergi, harcama, borçlanma vb.) aktif biçimde ekonomi içerisinde yer almasıdır. Ona göre bu yolla üretim ve istihdam artırılarak kişi başı gelir, tüketim ve harcamalar da harekete geçirilebilecektir. ${ }^{4}$

Günümüz liberal bakış açısı içerisinde ele alındığında sonra gelen görüşlerin, bu iki temel görüşün dönemsel eksikliklerini krizler vasıtasıyla görerek düzeltmeye çalıştığını söylemek yanlış olmayacaktır. Keynesyen bakış açısının yarattığı devlete biçilen roldeki artış zamanla bürokrasi ve hantallaşma, yozlaşma ve etkinlik kaybı gibi konular çerçevesinde değerlendirilmiş; buna karşın, klasik iktisadi görüşün yenilenen varyasyonları ise krizlerin önlenmesinde maliye politikasına yeterince yer vermediği gerekçesiyle etkili olamamakla eleştirilmiştir. Dolayısıyla, günümüzde de kamu gelir ve harcamalarının etkin kullanımı ile ulaşılması arzulanan iktisadi çıktı seviyesi arasındaki ilişkiye dair fikri bir uzlaşı sağlandığını söylemek güçtür.

Bu konuda yapılmış iktisadi literatürün öncü çalışmalarından birinde Solow (1956), Neo-klasik büyüme modeli içerisinde vergilerin ekonomik büyüme dengesini değiştirmeyeceğini belirtmiştir. Bir diğer deyişle, ona göre vergilerin esasen bozucu etkileri bulunmakla beraber uzun dönemde büyüme oranları ya da toplam faktör verimliliği üzerinde herhangi bir etki yaratmayacaklardır. Benzer şekilde, Friedman (1978) da vergilerin artırılmasının iktisadi büyüme üzerinde teoride arzu edilen olumlu etkileri yaratamayacağını, bunun sadece devlete ait mali alanı genişleteceğini savunmuştur.

Yine Solow'a göre (1956), kamu harcamaları da tıpkı vergiler gibi uzun dönemde büyüme dengesini değiştirmede etkisizdir. Neo-klasik bakış açısına göre; nüfus artış hızı, işgücü artış oranı ve dışsal bir değişken olarak teknoloji değişim seviyesi iktisadi büyüme değerlerinin ana belirleyicileridir. Öte yandan bu bakış açısından uzunca bir süre önce Wagner (1883), kamu harcamasının ekonomideki genel çıktı düzeyinin içsel bir faktörü olduğunu vurgulamıştır. Daha sonradan Wagner Kanunu olarak da adlandırılan bu denkliğe göre, bir ülkede iktisadi gelişme artış gösterdikçe kamu harcamalarındaki artışlar da kaçınılmaz olacaktır. Wagner, kamu harcamalarındaki artışı nominal (zahiri) ve reel (hakiki) olarak ikiye ayırmaktadır. Enflasyon, savaş nedeniyle ülke topraklarının genişlemesi, kamu hizmetlerinin bedellerinin artması kamu harcamalarını görünürde (nominal olarak) artıırken; eğitim, sağılı ve teknolojiye bağlı altyapı değiş̧imlerinin yarattığı maliyetler ise bu harcamaları gerçekte (reel olarak) artıracaktır.

Ekonomik büyüme ile kamu gelir ve harcamaları arasındaki bu ilişkinin dışında, kamu gelir ve giderlerinin kendi aralarında da bir bağlantı olduğu kimi araştırmacılarca dile getirilmiş ve bu alanda da kuvvetli bir literatür oluşmuştur. Maliye literatüründe kamu gelirleri ile giderleri arasındaki ilişkiyi tespitte dört temel hipotez kullanılmaktadır. Bunlar; i) Vergi-harcama, ii) Harcama-vergi, iii) Mali senkronizasyon (uyum), iv) Kurumsal farklılık (mali bağımsızlık) hipotezleridir.

"Vergi-harcama" hipotezi, Friedman (1978) tarafından ileri sürülmüştür. Buna göre; bütçe açıklarını kapatmaya yönelik olarak artırılan kamu gelirleri kamu harcamalarında artışı da beraberinde getirecektir. Bu nedenle vergi gelirlerini artırmak açık sorununu çözmede etkili değildir. Aksine, kamu harcamalarını kısılacağı ekonomi politikası uygulamaları bütçe açıklarını düşürmede tek yol olacaktır. Buchanan ve Wagner (1977) ise bu hipotezi bir başka şekilde yorumlamışlar ve vergi gelirlerini azaltmanın mali illüzyon (yanılsama) etkisi nedeniyle kamu harcamalarının artışına neden olacağını savunmuşlardı ${ }^{5}$. Bu nedenle vergi ve harcama değişkenleri arasındaki bu tek yönlü negatif ilişkiye Buchanan ve Wagner hipotezi adı da verilmektedir (Wagner, 1976; Buchanan ve Wagner, 1977).

İkinci görüş, Roberts (1978) ile Peacock ve Wiseman (1979) tarafından ileri sürülen "harcama-vergi" hipotezidir. Buna göre, savaşlar ve krizler gibi olağanüstü dönemlerde kamu harcamaları sıçrayışlar gösterir ve fakat bu dönemler sona erdiğinde eski düzeylerine dönmemektedir. Bu harcamaları finanse etmek için ise başta vergiler olmak üzere öngörülen tüm kamu gelirlerinin artırılması kaçınılmazdır. Dolayısıyla, eğer mali 
yönetim kamu harcamalarını kısmak konusunda üzerine düşen gayreti gösterecek maliye politikası uygulamalarına girişirse bu durum bütçe açıklarının azalmasını sağlayabilir. Yine bu hipotezi temel alan bir diğer analiz Barro (1979) tarafından yapılmıştır. Bu çalışmaya göre, vergilerde bugün ortaya çıkacak bir azalış gelecekte bugün oluşacak farkın da üzerine eklendiği çok daha yüksek miktarlarda vergilemeyi beraberinde getirecektir. Kamu harcamaları bir sonraki dönemde daha fazla vergiyle finanse edilmek durumunda kalacak ve bu anlamda harcama vergiyi belirleyen, şekillendiren ana unsur haline dönüşecektir. Barro (1979) da Ricardocu denklik hipotezinde olduğu gibi bütçe dengesinin kamu harcamalarının kısılmasından geçtiğini değerlendirmektedir.

Üçüncü görüş, Musgrave (1966) ile Meltzer ve Richard (1981) tarafından öne sürülen "mali senkronizasyon" ya da "mali uyum" hipotezidir. Bu hipotez adından da anlaşılacağı üzere her iki maliye politikası aracının da birbirini eşanlı olarak etkilediği varsayımına dayanmaktadır. Bu bakış açısına göre, kamu gelirleri ile hükümet harcamaları arasında karşılıkı bir nedensellik durumu söz konusudur. Dördüncü ve son hipotez ise "kurumsal farkııık" ya da "mali bağımsızlık" olarak adlandırılmaktadır. Buna göre, kamu gelirleri ile giderleri arasında herhangi bir ilişki bulunmamaktadır. Bir diğer deyişle, kamu gelir ve giderleri birbirlerinden bağımsız olarak hareket etmektedirler (Wildavsky, 1988; Bagestani ve McNown, 1994). Yine bu bakış açısına göre, gelir ve giderleri belirleyen asli unsur ihtiyari (iradi) mali politikalar ya da kamusal karar mekanizmaları olmaktadır.

\subsection{Ampirik Literatür}

Kamu ekonomisinin iktisadi büyüme üzerindeki etkilerini inceleyen çalışmalar özellikle iki değişken üzerinde odaklanmaktadır. Bunlar bir hükümetin bir kamusal mal ve hizmeti gerçekleştirebilme sınırlarına dair bize ipucu veren kamu gelirleri ve giderleridir. Son çeyrek asırda, büyümenin bu iki değişkenle etkileşimini analiz etmek üzere gerek kuramsal gerekse deneysel yazın içerisinde çeşitli çalışmalar yapılmıştır. Bu çalışmaların çok az bir kısmı gelir, harcama ya da servet vergilerinin ekonomik aktivite çıktı seviyesini azalttığı yönünde sonuçlara ulaşmıştır (Lee ve Gordon, 2005; Ojede ve Yamarik, 2012; Amir vd., 2013, Adkisson ve Mohammed, 2014). Buna ek olarak, Bujang vd. (2013) ise 24 gelişmekte olan 24 de gelişmiş ülkeyi ele aldığı çalışmasında, 10 yıllık bir dönem için geliş̧iş ülkelerde vergi yapısının ekonomik büyümeyi etkilemediğini buna karşın gelişmekte olan ülkelerde böyle bir etkileşimin bulunabileceği tespitine ulaşmıştır. Easterly ve Rebelo (1993) ise gelir vergisinin iktisadi büyüme değerlerini olumlu etkilediği buna karşın gümrük vergilerinin ise bunu kötüleştirdiğini belirtmektedirler.

Benzer şekilde, çoğunlukla kamu harcamaları ve vekâleten onu gösteren değişkenler ile ekonomik büyüme ve kişi başı gelir değişimlerinin kıyaslandığı çalışmalarda da karışık sonuçlara ulaşıldığı görülmektedir. Barro (1991), 1960 ile 1985 arası dönemi 98 ülke için ele aldığı çalışmasında kamu harcamaları ile ekonomik büyüme arasında negatif bir ilişkiye rastlamıştır. Hitiris ve Posnett (1992), 20 OECD ülkesini 28 yıl için inceledikleri çalışmalarında, kamu harcamalarının belirli bir düzeyinin hükümetlerce sağlık hizmetlerine yönlendirilmesi halinde kişi başı gelir üzerinde olumlu etki yaratılabileceği sonucuna ulaşmışlardır. Kneller vd. (1999) en küçük kareler yöntemi, havuz ve sabit etkiler modellemelerini kullandıkları panel veri analizlerinde 1970 ile 1995 yılları arası dönem için 22 gelişmiş ülkeyi incelemişler ve kamu harcamalarının kişi başı gelir artışlarını olumlu etkilediğini tespit etmişlerdir. Öte yandan, bu çalışmada vergilerin ise aynı değişkeni negatif yönde etkilediği sonucuna varılmıştır. Cooray (2009) GMM yönteminden faydalandığı panel veri analizinde 71 gelişmiş ve gelişmekte olan ülkeyi test etmiş ve kamu harcamaları ile ülkedeki yönetişim kalitesinin ekonomik büyümeyi pozitif yönde etkilediğine dair bulgulara ulaşmıştır. Yine, Dzhumashev (2014) de kamu harcamalarının büyüme üzerindeki başarısını yönetişimdeki etkinlik ve yozlaşma seviyesinin azlığı ile ilişkilendirmiştir. Buna karşın, çalışmaya göre mali saydamlığın görece sağlandığı bir ekonomide vergileme ise yolsuzluk, rüşvet ve benzeri riskleri azaltarak ekonomik büyüme değerlerini olumlu yönde etkileyebilecektir.

Bu çalışmada önceki çalışmalardan farklı olarak, kamu gelir ve harcamalarının (büyüme ve kişi başı gelir üzerindeki etkileri ötesinde), ilgili ülkeler ve zaman aralığı için birbirlerini etkileyip etkilemediklerine de odaklanılacağından bu konudaki ampirik literatür de taranmış ve sınırlı sayıda çoklu (panel) ülke analizi ile karşılaşılmıştır. Konunun sadece bu yönünü irdeleyen erken dönem çalışmasında Owoye (1995), 1961-1990 dönemi için bazı G7 ülkelerinde çift yönlü etkileşime rastlamış, bazılarında ise kamu gelirlerinin harcamaları 
etkilediği sonucuna varmıştır. Payne (1998) 1942-1992 dönem aralığında ABD eyaletleri için benzer bir sınamayı gerçekleştirmiş, tüm değişkenlerin birbirini tetikleyebildiğini tespit etmiştir. Benzer çok yönlü etkileşim, 1949-1995 dönemi 8 Latin Amerika ülkesini inceleyen Cheng (1999); 10 endüstrileşmiş ülkenin 1951-1996 dönemini inceleyen Chang, Liu ve Caudil (2002); 1950-2000 dönem aralığı için 12 gelişmekte olan ülkeyi inceleyen Narayan ve Narayan (2006) için de söz konusudur.

Takip eden dönemde, Konukçu-Önal ve Tosun (2008) 1999-2007 dönemi için çeyrek yıllık verilerle 4 geçiş ekonomisini incelemiş ve iki ülke için kamu gelirlerinin harcamaları iki ülke içinse çift yönlü etkileşim olduğu sonucuna ulaşmıştır. Afonso ve Rault (2009) 1960-2006 için 25 AB ülkesini incelemişler ve beş ülke için harcamadan gelire, dört ülke içinse gelirden harcamaya nedensellik bulmuşlardır. Chang ve Chang (2009), 1992-2006 dönem için 15 OECD ülkesini; Mehrara, Pahlavani ve Elyasi (2011) ise 1995-2008 dönem aralı̆̆ında 40 Asya ülkesini çalışmalarına konu almış ve iki değişken arasında çift yönlü nedensellik bulmuşlardır. Benzer yöntemle yapılan bir diğer çalışmada Westerlund, Mahdavi ve Firoozi (2011), 1963-1997 dönemi 50 ABD yerel yönetimi için gelirlerin giderleri belirlediği sonucuna ulaşmışlardır. Konu özelinde görece yakın dönemde yapılan son beş çalışmada ise, Paleologou (2013) 3 AB ülkesi için 1965-2009 döneminde; Bolat (2014) 10 AB ülkesi için 1980-2013 döneminde; Mutascu (2015 ve 2016) 4 AB ülkesi için 1988-2014 ve 10 Doğu Avrupa ülkesi için 1995-2012 dönemlerinde; Shastri, Giri ve Mohapatra (2017) ise 5 Güney Asya ekonomisinin 19852014 dönem aralığı için (farklı ülkelerde) iki yönlü ve bazı ülkeler için de çift yönlü istatistiki ilişkiyle karşılaşmışlardır.

Geçmiş çalışmalardan da görüldüğü üzere, gerek ekonomik büyüme ve kişi başı GSYiH değişimleri açısından gerekse de kamu gelir ve giderlerinin kendi aralarındaki ilişki açısından ortaya çıkan sonuçlar karmaşık sonuçlar vermiştir. Yukarıda değinilen teorik altyapı ve ampirik çalışmalar doğrultusunda, bu çalışma, takip eden bölümlerde söz konusu çalışmaların analizlerini uygun ve güncel yöntemlerle modelleyecek; fakat bu sefer değinilen tüm temel değişkenler ile hem ülkeler bazında hem de bütün bir panel olarak sonuçları değerlendirme çabasında olacaktır.

\section{Değişkenlerin Tanımlanması, Veri Seti ve Metodoloji}

Çalışmada yararlanılacak iki adet bağımlı ve iki adet bağımsız (ters yönlü etkileşimleri de sınanacaktır) değişken ile oluşturulacak veri setine, uygulanması düşünülen yönteme dair kuramsal ve deneysel prosedüre ilerleyen alt başlıklarda yer verilmektedir.

\subsection{Değişkenlerin Tanımlanması ve Veri Seti}

Analizlerde, uluslararası düzeyde bilinirliği olan kuruluşlara (Dünya Bankası, IMF, OECD) ait sayfalardan (her bir değişken ve ülke için aynı kaynaktan olmak kaydıyla) konsolide edilmiş bir veri seti kullanıımıştır. Türkiye için ek olarak Hazine ve Maliye Bakanlığı resmi internet sitesinden yararlanılmıştır. Panel veri analizi içerisinde nedenselliği araştırmada makul bir istatistiksel yöntem olarak (veri setine de uygunluğu doğrultusunda) bootstrap panel Granger nedensellik analizi tercih edilerek tahminler gerçekleştirilmiştir. Çalışma hem veri seti hem uygulama yönüyle öncüllerinden farklılıklar içermektedir. Öncelikle OECD üyesi ve paydaş ülkelerden seçilen havuzda ülkelerin mümkün ölçüde G7, G20, AB (PIIGS ${ }^{6}$ dâhil), BRICS ve yükselen gelişmekte olan ülkeler içerisinde yer alıyor olmasına özen gösterilmiştir. Yine, Dünya Bankası'nın 'Üst Orta ve Üst Gelir" gruplaması ülke seçimine esas teşkil etmiştir. Ülkeler, belirli temel özellik ve büyüklüklere haiz olmaları (nüfus, yüzölçümü, küçük ada ülkesi olmamaları, OPEC ve benzeri doğal kaynak yoğun ülkeler yerine reel üretimde bulunmaları) gibi kıstaslar altında bir ya da birkaç alanda başat özellik taşıyan ekonomiler ve 2008 Küresel Krizi'nden görece yoğun etkilenen ülkelerin bir bileşkesi olarak seçilmiştir. Sözü edilen çerçevede, gelişmiş ve gelişmekte olan çeşitli ülkelerle yapılacak analizlerde Türkiye ile birlikte 21 diğer ülke ekonomisi yer almaktadır. Çalışmada yer alan bu ülkeler sırasıyla; ABD, Almanya, Avustralya, Avusturya, Belçika, Birleşik Krallık, Finlandiya, Fransa, Güney Afrika, Güney Kore, Hollanda, İrlanda, İspanya, İsrail, İsveç, İtalya, Japonya, Kanada, Meksika, Portekiz, Türkiye ve Yunanistan'dır.

Öte yandan, çalışmada tüm ülke verileri 1985-2017 yıl aralığı için eksiksiz olarak elde edilmiştir. Yine bu noktada belirtmek gerekir ki, deneye dayanan analizlerde bazı gelişmiş ve gelişmekte olan ülkelerin 
yüzölçümü ve ölçek küçüklüğü, nüfusun azlığı (küçük ada ülkeleri gibi), veri noksanlığı veya yoğun doğal kaynaklara sahip olunması (OPEC vb.) gibi gerekçelerle araştırma kapsamının dışarısında tutulmasının ampirik tutarlıık açısından makul olacağı değerlendirilmiştir. Bu şekilde yapılacak modellemeler vasıtasıyla, nihai olarak, ülkelerin iktisadi ve mali yapısına dair tümdengelim-tümevarım bağlantılarının kurulabileceği düşünülmektedir. Iktisadi performans göstergeleri ile ilgili ülkelere ait mali değişkenler karşlıklı olarak irdeleneceği için tüm modellerin ortak sonuçlarının yorumlanmasıyla maliye politikalarına dair çıkarsamalar da yapılabilecektir. Bu sebeple, elde edilecek ampirik bulguların akademisyenler ve politika yapıcılar açısından yol gösterici olacağı değerlendirilmektedir. Kullanılacak ülke grubu ve veri seti ve ötesinde, bu verilerin tanımlanması Tablo 1'de gösterilmiştir. Ekonometrik modellerin teorik çözümlemesi ise takip eden bölümde tüm aşamalarıyla sunulmaktadır.

Tablo 1. Verilerin Tanımlanması

\begin{tabular}{|l|l|c|}
\hline Değişken & Tanımı & Kaynak* \\
\hline GSYH & Gayrisafi Yurtiçi Hâsıla Yıllık \% Büyüme (Değişim) Değerleri & $D B(2019)$ \\
\hline KBGSYH & Kişi Başı Gayrisafi Yurtiçi Hâsıla Yıllık \% Büyüme Değerleri & $D B(2019)$ \\
\hline KHARC & Toplam Kamu Harcamaları/ Gayrisafi Yurtiçi Hâsıla & IMF, OECD \\
& (2018-2019) \\
\hline KGEL & Toplam Kamu Gelirleri/ Gayrisafi Yurtiçi Hâsıla & $\begin{array}{c}\text { IMF, OECD } \\
\text { (2018-2019) }\end{array}$ \\
\hline
\end{tabular}

Not: *Toplam kamu gelir ve harcamalarının GSYiH değerlerine oranlanmasında, sırasıyla; IMF (WEO) ve Dünya Bankası (WDI) veri setlerinden yararlanılmıştır. Yine, Türkiye verileri OECD (oecd.stat) ile T.C. Hazine ve Maliye Bakanlığı resmi internet sayfaları üzerindeki istatistiki verilerin konsolide edilmesi suretiyle yazar tarafından derlenmiş ve/veya hesaplanmıştır.

\subsection{Metodoloji}

Maliye politikası değişkenlerinin GSYiH ile olan karşılıklı etkileşimini iki bağımlı ve iki bağımsız değişken ile 'ayrı ayrı' tekrarlayarak incelemek; böylelikle, daha gerçekçi sonuç ve yorumlara ulaşmak bu çalışmanın ana hedefidir. Nedensellik ilişkilerini amaçlar çerçevesinde ampirik araçlarla analiz etmeye çalışılırken yönteme uygun konu seçimi değil konuya olası en uygun yöntemin seçilmesi hususuna özen gösterilmiştir. Süregelen mali politikaların ve ekonomik performans göstergelerinin birbirlerini belirlemedeki rolünü toplu bir biçimde, zaman-mekân bütünlüğü içerisinde inceleyen ve değerlendiren yakın dönem ampirik çalışma yok denecek kadar azdır. Geçmiş araştırmalar yöntemleri itibariyle incelenmiş ve önceki bölümlerde de belirtildiği üzere yapılan planlamada bootstrap panel nedensellik ${ }^{7}$ analizinin araştırmamız açısından kullanılmasının makul olacağına kanaat getirilmiştir. ${ }^{8}$

Temel tanımı itibariyle panel veri analiz yöntemi, zaman boyutuna ait kesit verilerinin kullanılması ile iktisadi etkileşimlerin tahmin edilmesi olarak ifade edilebilir (Greene, 2003: 612). Bu yöntem ülke, hanehalkı, firma, çalışanlar ve benzer kesitlere ait gözlemlerin belirli zaman aralığı için bir konsolide edilmesinden ibarettir (Baltagi, 2001: 1; Arellano, 2003: 1). Panel veri analizlerinde nedenselliğin yönünü incelemede uygulanabilen üç farklı tahmin yöntemi mevcuttur. İlk tahmin yöntemi, sabit etkileri ortadan kaldırarak modeli analiz eden genelleştirilmiş dönemler yöntemi (GMM) tahmincisi aracılığıyla gerçekleştirilen vektör hata düzeltme modeli (VECM) tahmincisidir. Fakat bu yaklaşım heterojenliği ve yatay kesit bağımlılığını dikkate alıp açıklamamaktadır. Bu durum, yöntemin kullanmasının önünde duran en büyük engeldir. íkinci tahmin yöntemi, Hurlin (2008) tarafından geliştirilen nedensellik yöntemidir. Bu yöntem, heterojenliği açıklayan fakat yatay kesit bağımlılı̆ını dikkate almayan bir panel veri nedensellik testi sunmaktadır. Heterojenliği dikkate alan yöntem bu üstünlüğüne rağmen modelde önemli sapmalar ve boyut bozulmalarına neden olabilmektedir. Ancak, Kónya (2006) tarafından geliştirilmiş olan üçüncü yaklaşım hem heterojenliği hem de yatay kesit bağımlılığını dikkate almakta ve bu özelliği nedeniyle her iki nedensellik yöntemi üzerinde göreceli bir üstünlüğe sahip olmaktadır. ${ }^{9}$

Genel olarak, Kónya'nın (2006) modeli diğer nedensellik testlerine göre üç temel üstünlüğe sahiptir: 
i) Ülkeler arası yatay kesit bağımlılı̆ını hesaba katan regresyon (SUR) tahminine dayanmaktadır;

ii) Her ülkeye özgü hesaplanan bootstrap kritik değerleri Wald istatistiğine dayanmaktadır, öte yandan, bu yaklaşım bir panelin tüm üyeleri için ortak hipotez gerektirmemektedir;

iii) Birim kök testlerinin etkilerinin düşük olabileceği gerçeği göz önüne alındığında, seriler arasında birim kök ve eşbütünleşmenin sağlanması şartı aranmamaktadır.

Dolayısıyla, Kónya'nın (2006) modeli durağan olmayan ve eşbütünleşmenin de sağlanmadığı serilere kolaylıkla uygulanabilmektedir. Bir başka deyişle, yapısal kırılmaları dikkate alan bootstrap panel nedensellik modellerini uygulayabilmek için analizde kullanılan serilerin durağan ve eşbütünleşik olmalarına ihtiyaç yoktur.

Bilindiği üzere nedensellik analizi, ekonometrik yazında, bir değişkenin bir diğerini etkileme ya da tahminlemesinde değişikliklere yol açabilme durumu olarak ifade edilmektedir (Asteriou ve Hall, 2007). Bu çerçevede, özellikle de uygulamalı ekonometri alanında Granger nedenselliği (Granger, 1969) sıklıkla başvurulan bir kavramdır. Granger nedenselliği tanımına göre geçmiş, bugün ya da gelecekten etkilenmemektedir. Zaman boyutunda olaylar ardı ardına gelişmektedir. Bu nedenle nedensellik daima ilk olaydan ikinci olaya doğru ortaya çıkmaktadır. Granger zaman serilerinde ortaya çıkan nedenselliği test etmek üzere bir prosedür ortaya koymuştur (Hacker ve Hatemi-J, 2006: 1489-1490).

Granger aşağıda sunulan modele açıklayıcı değişkenin gecikmeli değerlerinin (Xt-i) yanı sıra bağımlı değişkenin de gecikmelerini (Yt-i) koymuştur. Eğer bağımlı değişkenin (Yt-i) kendi gecikmeleri modelde var iken bağımsız değişkenin gecikmeleri (Xt-i) beraberce istatistiki olarak anlamsız ise nedensellik ilişkisi bulunmamaktadır. $H_{0}$ hipotezinin reddi ise $X^{\prime}$ ten $Y^{\prime}$ ye doğru Granger nedensellik ilişkisi olduğu anlamına gelmektedir. Panel nedensellik analiz sistemi iki denklik seti ile ifade edilmektedir ve aşağıdaki şekilde yazılabilir (Chu, Chang ve Sagafi-nejad, 2016: 34);

$$
\left\{\begin{array}{c}
y_{1, t}=\alpha_{1,1}+\sum_{l=1}^{p_{1}} \beta_{1,1, l} y_{1, t-l}+\sum_{l=1}^{p_{1}} \delta_{1,1, l} x_{1, t-l}+\varepsilon_{1,1, t} \\
y_{2, t}=\alpha_{1,2}+\sum_{l=1}^{p_{1}} \beta_{1,2, l} y_{2, t-l}+\sum_{l=1}^{p_{1}} \delta_{1,2, l} x_{2, t-1}+\varepsilon_{1,2, t} \\
\vdots \\
y_{N, t}=\alpha_{1, N}+\sum_{l=1}^{p_{1}} \beta_{1, N, l} y_{N, t-l}+\sum_{l=1}^{p_{1}} \delta_{1, N, l} x_{N, t-1}+\varepsilon_{1, N, t}
\end{array}\right.
$$

Çalışmamı özelinde düşünüldüğünde, y gayrisafi yurtiçi hâsıla yüzde (\%) değişim değerlerini (GSYH) ve kişi başı GSYiH artış oranlarını (KBGSYH) gösterirken $\mathbf{x}$ ise kamu gelirlerinin (KGEL) ve kamu harcamalarının (KHARC) GSYiH içerisindeki yüzde (\%) payını göstermektedir (tersleri de sınanacaktır). Yine aynı doğrultuda, karşııklı nedensellik ilişkisini sorgulayacak ikinci denklik ise aşağıdaki gibidir;

$$
\left\{\begin{array}{c}
x_{1, t}=\alpha_{2,1}+\sum_{l=1}^{p_{2}} \beta_{2,1, l} y_{1, t-l}+\sum_{l=1}^{p_{2}} \delta_{2,1, l} x_{1, t-l}+\varepsilon_{2,1, t} \\
x_{2, t}=\alpha_{2,2}+\sum_{l=1}^{p_{2}} \beta_{2,2, l} y_{2, t-l}+\sum_{l=1}^{p_{2}} \delta_{2,2, l} x_{2, t-1}+\varepsilon_{2,2, t} \\
\vdots \\
x_{N, t}=\alpha_{2, N}+\sum_{l=1}^{p_{2}} \beta_{2, N, l} y_{N, t-l}+\sum_{l=1}^{p_{2}} \delta_{2, N, l} x_{N, t-1}+\varepsilon_{2, N, t}
\end{array}\right.
$$


Yukarıdaki denklikte $\boldsymbol{N}$ panel sayısını $(j=1, \ldots, N), \boldsymbol{t}$ zaman dilimlerini $(t=1, \ldots, T), I$ ise gecikme uzunluğunu ifade etmektedir. Bu sistem tanımında, her denkliğin birbirinden farklı önceden belirlenmiş değişkenleri bulunmakta ancak hata terimleri yatay kesit bağlamında birbirleriyle korelasyon içerisinde olabilmektedir ve dolayısıyla denklik setlerinin her biri birer SUR analiz sistemini oluşturmaktadır. Bu sistemde Granger nedensellik testi yapabilmek için her ülke seti açısından şu şekilde alternatif nedensellik ilişkileri bulunabilir olmalıdır:

a. Eğer tüm $\delta_{1, i}$ değerleri sıfır değilse ama $\beta_{2, j i}$ değerleri sıfırsa $X^{\prime}$ ten $Y^{\prime}$ ye tek yönlü Granger nedensellik bulunmaktadır;

b. Eğer tüm $\beta_{2, j i}$ değerleri sıfır değilse ama $\delta_{1, i}$ değerleri sıfırsa $Y^{\prime}$ den $X^{\prime}$ e tek yönlü Granger nedensellik bulunmaktadır;

c. Eğer hem $\delta_{1, i}$ değerleri hem de $\beta_{2, j i}$ değerleri sıfırdan farklıysa $X$ ve $Y$ arasında çift yönlü Granger nedensellik ilişkisi bulunmaktadır;

d. Eğer tüm $\delta_{1, i}$ ve $\beta_{2, j i}$ değerleri sıfır ise $X$ ile $Y$ değişkenleri arasında Granger nedensellik ilişkisi bulunmamaktadır. ${ }^{10}$

Öte yandan, Kónya (2006) optimal gecikme uzunluğunun belirlenmesinin çok önemli olduğunu vurgulamaktadır. Çünkü nedensellik sonuçları büyük ölçüde buna bağlı olacaktır. Az sayıda gecikme değeri, bazı önemli değişkenlerin modelden çıkarılmasına neden olacak ve bu tür bir spesifikasyon hatası ise elde tutulan katsayı değerleriyle yapılacak regresyonda sapmalara yol açacaktır. Bu durumun aksine, çok sayıda gecikme değeri kullanılması çok sayıda gözlemin elemine edilmesi anlamı taşıyacak ve bu neviden bir tanımlama hatası ise genellikle tahmini yapılan katsayıların standart hatalarında yükselmeye neden olacaktır.

Sonuç olarak, her iki değerlendirme de tutarsız sonuçların ortaya çıkması anlamı taşıyacaktır. Dolayısıyla, görece büyük bir panel veri setinde optimal gecikme yapısını tespit edebilmek için Kónya'nın prosedür ve yaklaşımı takip edilerek gecikmelerin denklikler arasında aynı kalmasına ve fakat değişkenler arasında farklı değerlere ulaşabilmesine müsaade edilecektir. Bu çerçevede, yöntemin kullanıldığı diğer alan çalışmaları ve örneklemler de dikkate alınarak tahminlerin bir ila dört gecikme değeri arasında ve SchwarzBayesian enformasyon kriteri doğrultusunda gerçekleştirilmesi planlanmıştır.

\section{Ampirik Bulgular}

Çalışmanın bulguları iki ana kısımdan oluşmaktadır. Illk aşamada, yatay kesit bağımlılığı ile heterojenite testleri gerçekleştirilmiştir. Söz konusu ön testlere ait açıklama ve sonuçlar (yatay kesit bağımlılığı ve homojenite test bulguları) Ek 3 'te ortaya konulmaktadır. ${ }^{11}$ ikinci aşamadaysa bootstrap panel Granger nedensellik test sonuçlarına yer verilmiştir. Takip eden tablolarda bu analizlere ait sonuçlar ve yorumlar yer almaktadır.

Tablo 2. KHARC ve KGEL ile GSYH Arası İstatistiksel İlişkiye Dair Panel Nedensellik Sonuçları

\begin{tabular}{|c|c|c|c|c|c|c|c|c|}
\hline \multirow[b]{3}{*}{ Ülkeler } & \multicolumn{4}{|c|}{$\mathrm{H}_{0}:$ KHARC, GSYH'in nedeni değildir } & \multicolumn{4}{|c|}{$\mathrm{H}_{0}$ : GSYH, KHARC'ın nedeni değildir } \\
\hline & \multirow[b]{2}{*}{ İstatistik } & \multicolumn{3}{|c|}{ Bootstrap Kritik Değerleri } & \multirow[b]{2}{*}{ İstatistik } & \multicolumn{3}{|c|}{ Bootstrap Kritik Değerleri } \\
\hline & & $\% 1$ & $\% 5$ & \%10 & & \%1 & $\% 5$ & $\% 10$ \\
\hline$A B D$ & 8,230 & 38,931 & 21,404 & 14,767 & 2,876 & 336,600 & 225,267 & 183,244 \\
\hline Almanya & 2,358 & 59,246 & 33,977 & 25,031 & 23,187 & 291,526 & 179,438 & 138,234 \\
\hline Avustralya & 3,052 & 54,581 & 27,886 & 19,038 & 40,801 & 211,704 & 128,053 & 95,256 \\
\hline Avusturya & 0,046 & 40,770 & 21,243 & 14,501 & 58,211 & 366,263 & 209,447 & 154,255 \\
\hline Belçika & 0,063 & 41,050 & 21,772 & 14,896 & 44,959 & 347,686 & 228,514 & 183,213 \\
\hline Birleşik Krallık & 0,976 & 41,450 & 21,243 & 14,440 & 40,413 & 372,830 & 247,108 & 197,314 \\
\hline Finlandiya & 10,432 & 43,696 & 22,712 & 15,616 & 32,006 & 271,293 & 156,775 & 114,971 \\
\hline Fransa & 0,285 & 51,862 & 24,958 & 17,075 & $143,679 *$ & 270,230 & 161,414 & 125,424 \\
\hline Güney Afrika & 0,245 & 88,659 & 53,717 & 38,357 & 27,811 & 241,862 & 137,492 & 94,766 \\
\hline Güney Kore & 0,043 & 56,536 & 28,495 & 19,271 & 162,203 & 329,770 & 212,347 & 166,576 \\
\hline Hollanda & $24,165^{* *}$ & 43,307 & 22,621 & 15,336 & 10,666 & 293,003 & 187,399 & 141,965 \\
\hline İrlanda & 6,709 & 68,723 & 37,455 & 25,327 & 35,309 & 329,040 & 201,388 & 153,779 \\
\hline
\end{tabular}


Tablo 2. KHARC ve KGEL ile GSYH Arası İstatistiksel Ilişkiye Dair Panel Nedensellik Sonuçları (Devamı)

\begin{tabular}{|c|c|c|c|c|c|c|c|c|}
\hline \multirow[b]{3}{*}{ Ülkeler } & \multicolumn{4}{|c|}{$\mathbf{H}_{0}$ : KHARC, GSYH'in nedeni değildir } & \multicolumn{4}{|c|}{$\mathbf{H}_{0}$ : GSYH, KHARC'ın nedeni değildir } \\
\hline & \multirow[b]{2}{*}{ İstatistik } & \multicolumn{3}{|c|}{ Bootstrap Kritik Değerleri } & \multirow[b]{2}{*}{ İstatistik } & \multicolumn{3}{|c|}{ Bootstrap Kritik Değerleri } \\
\hline & & $\% 1$ & $\% 5$ & \%10 & & \multirow{2}{*}{\begin{tabular}{|c|} 
\%1 \\
300,871
\end{tabular}} & \multirow{2}{*}{$\begin{array}{c}\text { \%5 } \\
198,414\end{array}$} & $\frac{\text { eri }}{\% 10}$ \\
\hline İspanya & 3,151 & 65,659 & 36,158 & 26,685 & 7,596 & & & 153,311 \\
\hline İsrail & 2,071 & 56,810 & 30,687 & 21,152 & 0,012 & 401,566 & 250,148 & 195,428 \\
\hline İsveç & 25,885 & 80,812 & 45,028 & 30,819 & 2,105 & 288,384 & 170,264 & 121,964 \\
\hline İtalya & 2,093 & 47,426 & 25,327 & 17,093 & 7,205 & 320,446 & 202,041 & 155,127 \\
\hline Japonya & 0,361 & 58,619 & 29,560 & 19,706 & 27,877 & 381,897 & 253,659 & 201,011 \\
\hline Kanada & 0,496 & 70,087 & 36,862 & 25,344 & $218,261 * *$ & 291,324 & 183,635 & 140,592 \\
\hline Meksika & 16,786 & 55,404 & 28,207 & 18,421 & 114,101 & 337,580 & 193,114 & 142,969 \\
\hline Portekiz & 14,575 & 50,857 & 27,370 & 18,839 & 67,722 & 316,852 & 211,013 & 164,752 \\
\hline Türkiye & 9,021 & 35,281 & 19,965 & 13,870 & 21,366 & 247,683 & 148,330 & 109,735 \\
\hline Yunanistan & 1,250 & 90,242 & 54,378 & 40,848 & 76,673 & 336,894 & 211,122 & 164,641 \\
\hline \multirow[b]{3}{*}{ Ülkeler } & \multicolumn{4}{|c|}{$\mathbf{H}_{0}:$ KGEL, GSYH'in nedeni değildir } & \multicolumn{4}{|c|}{$\mathrm{H}_{0}$ : GSYH, KGEL'in nedeni değildir } \\
\hline & \multirow[b]{2}{*}{ İstatistik } & \multicolumn{3}{|c|}{ Bootstrap Kritik Değerleri } & \multirow[b]{2}{*}{ İstatistik } & \multicolumn{3}{|c|}{ Bootstrap Kritik Değerleri } \\
\hline & & \%1 & $\% 5$ & $\% 10$ & & \%1 & $\% 5$ & $\% 10$ \\
\hline$A B D$ & 8,773 & 27,987 & 14,411 & 10,205 & 69,376 & 361,520 & 248,355 & 202,404 \\
\hline Almanya & 1,853 & 31,235 & 16,304 & 10,852 & 47,771 & 333,672 & 211,554 & 166,068 \\
\hline Avustralya & 1,726 & 41,514 & 22,152 & 14,942 & 0,054 & 249,436 & 157,781 & 122,027 \\
\hline Avusturya & 0,001 & 31,588 & 17,040 & 11,550 & 37,182 & 384,655 & 226,805 & 168,015 \\
\hline Belçika & 0,347 & 32,923 & 17,706 & 12,434 & 0,084 & 347,758 & 229,325 & 183,572 \\
\hline Birleşik Krallık & 0,341 & 30,438 & 16,094 & 10,893 & 96,366 & 356,243 & 232,481 & 183,285 \\
\hline Finlandiya & 10,084 & 29,635 & 15,406 & 10,333 & 118,781 & 346,768 & 202,556 & 151,825 \\
\hline Fransa & 0,007 & 40,350 & 21,649 & 14,349 & 103,307 & 274,641 & 176,033 & 137,523 \\
\hline Güney Afrika & 0,215 & 61,547 & 35,358 & 25,333 & 70,442 & 305,927 & 198,891 & 151,637 \\
\hline Güney Kore & 0,014 & 60,998 & 30,221 & 20,698 & 21,301 & 294,355 & 194,783 & 150,901 \\
\hline Hollanda & $15,451^{*}$ & 33,687 & 18,979 & 12,900 & 1,098 & 293,076 & 193,940 & 149,070 \\
\hline İrlanda & 2,677 & 44,253 & 25,324 & 17,232 & 5,287 & 293,622 & 186,130 & 142,956 \\
\hline İspanya & 1,757 & 31,064 & 16,935 & 11,815 & 198,746 & 361,617 & 252,162 & 204,038 \\
\hline İsrail & 1,551 & 52,808 & 27,443 & 18,579 & 5,744 & 328,866 & 212,721 & 166,251 \\
\hline İsveç & $17,083^{* *}$ & 31,799 & 17,018 & 11,711 & 192,502 & 364,854 & 244,929 & 200,847 \\
\hline İtalya & 3,113 & 42,422 & 23,615 & 16,106 & 3,076 & 281,709 & 172,231 & 133,473 \\
\hline Japonya & 0,203 & 51,897 & 25,915 & 17,556 & 12,501 & 341,020 & 226,437 & 180,575 \\
\hline Kanada & 0,041 & 51,187 & 28,185 & 19,706 & $239,563 * *$ & 332,942 & 222,640 & 173,499 \\
\hline Meksika & $20,913^{*}$ & 54,995 & 27,266 & 18,154 & 18,606 & 341,934 & 193,336 & 143,065 \\
\hline Portekiz & 4,627 & 32,300 & 18,212 & 11,955 & $246,010^{*}$ & 383,198 & 260,635 & 212,176 \\
\hline Türkiye & 6,220 & 25,870 & 13,349 & 9,251 & 72,802 & 322,003 & 204,976 & 161,341 \\
\hline Yunanistan & 0,001 & 45,623 & 24,623 & 17,035 & 2,510 & 295,054 & 179,113 & 133,210 \\
\hline
\end{tabular}

Not: ${ }^{*}, * *$, ve ${ }^{* *}$ sırası ile \%10,\%5 ve \%1 anlamlılık seviyesinde $H_{0}$ hipotezinin reddedildiği anlamına gelmektedir. Bootstrap kritik değerleri 10000 tekrarlı dağııımdan elde edilmiştir. Uygun gecikme Schwarz-Bayesian bilgi kriterine göre belirlenmiştir. Maksimum gecikme sayısı 4'tür.

Tablo 2'de kamu harcamalarının ve gelirlerinin yıllar itibariyle GSYiH değişimleri ile olan karşııkı etkileşimine yer verilmiştir. Kamu harcamaları ile yapılan analizler sonucunda, Hollanda'da kamu harcamalarının GSYiH'in; Fransa ve Kanada'da ise GSYiH'in kamu harcamalarının nedeni olduğu sonucuna ulaşılmıştır. Bu durum Ek 1'deki kamu harcamaları ile GSYiH arası görünür ters yönlü ilişki çerçevesinde düşünüldüğünde, Hollanda'da kamu harcamaları artıkça ekonomik büyüme değerlerinin düşüş eğilimi (ters yönlü etkileşim) gösterdiği; buna karşın, Fransa ve Kanada'da ise (nedenleri ve tetikleyici unsurları farklı olabilirse de) ekonomik büyüme artıkça kamu giderlerinin azaldığı değerlendirilebilir. Bu düşüncenin istatistiksel olarak anlamlı olmasa dahi -en azından bazı yıllar için- pek çok ülke açısından doğru olduğu izlenimi de yine Ek 1'den edinilebilmektedir.

Diğer taraftan, ilişkiyi kamu gelirleri ile ekonomik büyüme değer değişimi çerçevesinde ele alığımızda ise Hollanda, İsveç, Meksika açısından kamu gelirlerinin GSYiH'in belirleyicisi olduğu görülmektedir. Aksine Kanada ve Portekiz'de ise GSYiH kamu gelirinin nedeni olarak karşımıza çıkmaktadır. Tablo 2'ye göre dört testin tümünde benzer tutarlılık gösteren iki ülke Hollanda ve Kanada olmuştur. Hollanda'da hem kamu 
gelirleri hem de harcamaları GSYiH'in analizler özelinde belirleyici unsuru olurken Kanada'da ise bu istatistiksel ilişkinin tam ters yönde kurulu olduğu gözlemlenmektedir. Bir diğer deyişle, bu ülkede GSYiH artış ve azalışları ile kamu gelir ve giderleri arasında kuvvetli bir bağlantı bulunmaktadır.

Tablo 3. KHARC ve KGEL ile KBGSYH Arası İstatistiksel Illişkiye Dair Panel Nedensellik Sonuçları

\begin{tabular}{|c|c|c|c|c|c|c|c|c|}
\hline \multirow[b]{3}{*}{ Ülkeler } & \multicolumn{4}{|c|}{$\mathbf{H}_{0}$ : KHARC, KBGSYH'in nedeni değildir } & \multicolumn{4}{|c|}{$\mathrm{H}_{0}$ : KBGSYH, KHARC'ın nedeni değildir } \\
\hline & \multirow[b]{2}{*}{ İstatistik } & \multicolumn{3}{|c|}{ Bootstrap Kritik Değerleri } & \multirow[b]{2}{*}{ İstatistik } & \multicolumn{3}{|c|}{ Bootstrap Kritik Değerleri } \\
\hline & & $\% 1$ & $\% 5$ & $\% 10$ & & $\% 1$ & $\% 5$ & \multirow{2}{*}{$\frac{\text { \%10 }}{183,095}$} \\
\hline$A B D$ & 5,092 & 36,292 & 19,686 & 13,018 & 16,164 & 333,422 & 224,996 & \\
\hline Almanya & \multirow{2}{*}{$\begin{array}{l}0,121 \\
4,856\end{array}$} & 52,595 & 29,94 & 20,779 & 23,127 & 295,365 & 180,712 & 136,74 \\
\hline Avustralya & & 54,986 & 28,734 & 19,298 & 37,946 & 218,969 & 127,209 & 93,345 \\
\hline Avusturya & 0,556 & 43,723 & 21,529 & 14,332 & 33,807 & 349,232 & 204,168 & 149,388 \\
\hline Belçika & 0,436 & 34,608 & 19,363 & 13,179 & 12,454 & 345,113 & 223,583 & 176,439 \\
\hline Birleşik Krallık & 0,195 & 40,954 & 21,685 & 14,531 & 82,751 & 380,48 & 247,978 & 194,417 \\
\hline Finlandiya & 6,926 & 40,762 & 21,359 & 14,324 & 58,116 & 268,053 & 152,955 & 114,559 \\
\hline Fransa & 0,714 & 46,925 & 25,283 & 16,939 & $166,673^{* *}$ & 255,75 & 159,985 & 123,576 \\
\hline Güney Afrika & 0,258 & 66,658 & 37,47 & 26,953 & 55,731 & 242,09 & 133,672 & 94,113 \\
\hline Güney Kore & 0,917 & 53,338 & 26,326 & 17,438 & $150,106 *$ & 295,886 & 192,278 & 149,925 \\
\hline Hollanda & 10,695 & 41,402 & 21,324 & 14,616 & 1,897 & 287,263 & 180,431 & 137,766 \\
\hline İrlanda & 4,951 & 66,052 & 35,75 & 24,718 & 49,36 & 314,198 & 201,481 & 152,646 \\
\hline İspanya & 2,366 & 62,861 & 37,19 & 26,142 & 19,739 & 292,015 & 186,299 & 141,672 \\
\hline İsrail & 1,319 & 54,464 & 28,501 & 19,297 & 34,019 & 334,098 & 212,773 & 163,12 \\
\hline İsveç & 22,9 & 75,758 & 40,217 & 26,562 & 4,139 & 261,761 & 150,073 & 106,155 \\
\hline İtalya & 2,794 & 38,003 & 21,345 & 14,564 & 2,013 & 289,867 & 183,005 & 143,907 \\
\hline Japonya & 0,776 & 56,575 & 29,024 & 19,791 & 0,404 & 363,19 & 231,381 & 180,467 \\
\hline Kanada & 3,118 & 63,784 & 34,953 & 23,202 & $221,000 * *$ & 285,914 & 182,035 & 143,007 \\
\hline Meksika & $24,330 *$ & 55,941 & 28,333 & 18,39 & 50,541 & 336,753 & 194,777 & 145,637 \\
\hline Portekiz & 4,945 & 52,896 & 27,898 & 18,789 & 136,08 & 317,403 & 206,965 & 162,575 \\
\hline Türkiye & 4,346 & 37,191 & 19,552 & 13,285 & 20,697 & 225,005 & 143,226 & 109,273 \\
\hline Yunanistan & 0,508 & 77,535 & 45,448 & 32,945 & 99,972 & 327,705 & 204,154 & 154,351 \\
\hline \multirow[b]{3}{*}{ Ülkeler } & \multicolumn{4}{|c|}{$\mathrm{H}_{0}$ : KGEL, KBGSYH'in nedeni değildir } & \multicolumn{4}{|c|}{$\mathbf{H}_{0}: \mathrm{KBGSYH}, \mathrm{KGEL}$ 'in nedeni değildir } \\
\hline & \multirow[b]{2}{*}{ İstatistik } & \multicolumn{3}{|c|}{ Bootstrap Kritik Değerleri } & & \multicolumn{3}{|c|}{ Bootstrap Kritik Değerleri } \\
\hline & & $\% 1$ & $\% 5$ & $\% 10$ & İstatistik & $\% 1$ & $\% 5$ & $\% 10$ \\
\hline$A B D$ & 7,101 & 26,252 & 14,394 & 9,613 & 59,447 & 369,669 & 255,429 & 206,566 \\
\hline Almanya & 0,096 & 31,884 & 16,945 & 11,434 & 51,931 & 332,174 & 211,135 & 165,803 \\
\hline Avustralya & 3,144 & 40,947 & 21,018 & 14,293 & 1,606 & 251,524 & 154,732 & 117,624 \\
\hline Avusturya & 0,576 & 31,238 & 16,325 & 11,024 & 17,581 & 397,096 & 220,652 & 165,943 \\
\hline Belçika & 1,092 & 29,177 & 15,98 & 10,932 & 0,728 & 340,998 & 227,708 & 178,937 \\
\hline Birleşik Krallık & 0,088 & 28,377 & 15,874 & 10,86 & 103,666 & 368,583 & 233,966 & 185,916 \\
\hline Finlandiya & $10,609 *$ & 27,103 & 14,493 & 9,911 & 136,281 & 362,429 & 203,866 & 152,217 \\
\hline Fransa & 0,158 & 38,776 & 20,253 & 13,826 & 74,498 & 285,071 & 179,368 & 137,425 \\
\hline Güney Afrika & 0,026 & 39,886 & 23,8 & 17,697 & 106,276 & 304,406 & 190,373 & 146,589 \\
\hline Güney Kore & 0,02 & 49,278 & 24,71 & 16,015 & 0,029 & 288,921 & 181,673 & 142,084 \\
\hline Hollanda & 6,119 & 31,628 & 17,63 & 12,307 & 6,065 & 306,572 & 191,612 & 147,336 \\
\hline İrlanda & 2,42 & 43,556 & 24,459 & 16,896 & 0,057 & 290,608 & 177,927 & 132,94 \\
\hline İspanya & 0,913 & 27,883 & 15,438 & 10,892 & $228,976^{*}$ & 356,191 & 245,279 & 199,796 \\
\hline İsrail & 2,221 & 48,021 & 24,72 & 16,663 & 54,699 & 323,045 & 197,99 & 155,082 \\
\hline İsveç & $13,130 *$ & 29,841 & 15,94 & 10,758 & $204,998 *$ & 365,982 & 252,664 & 202,286 \\
\hline İtalya & 5,024 & 36,813 & 19,978 & 13,528 & 11,887 & 265,999 & 170,987 & 131,202 \\
\hline Japonya & 0,252 & 52,082 & 26,075 & 17,094 & 112,325 & 342,63 & 212,139 & 168,687 \\
\hline Kanada & 2,268 & 49,209 & 26,169 & 18,464 & $195,624^{*}$ & 348,742 & 227,84 & 179,385 \\
\hline Meksika & $31,599 * *$ & 48,556 & 25,864 & 16,888 & 0,929 & 326,665 & 197,693 & 149,628 \\
\hline Portekiz & 0,423 & 33,1 & 18,44 & 12,57 & $310,579 * *$ & 381,086 & 262,28 & 211,577 \\
\hline Türkiye & 4,214 & 26,987 & 14,356 & 9,892 & 69,587 & 306,083 & 196,747 & 155,205 \\
\hline Yunanistan & 3,37 & 34,531 & 18,545 & 12,603 & 0,001 & 271,534 & 173,935 & 131,134 \\
\hline
\end{tabular}

Not: *,**, ve *** sırası ile \%10, \%5 ve \%1 anlamlıık seviyesinde $H_{0}$ hipotezinin reddedildiği anlamına gelmektedir. Bootstrap kritik değerleri 10000 tekrarlı dağılımdan elde edilmiştir. Uygun gecikme Schwarz-Bayesian bilgi kriterine göre belirlenmiştir. Maksimum gecikme sayısı 4'tür. 
Yukarıda Tablo 3'te kamu harcamalarının ve gelirlerinin kişi başı GSYiH yüzde değişimler ile karşılıklı nedensellik sonuçları yer almaktadır. Buna göre, Meksika'da kamu harcamaları kişi başı GSYiH artışlarının; Fransa, Güney Kore ve Kanada'da ise kişi başı gelirdeki artışlar kamu harcamalarındaki değişimlerin önemli gerekçelerindendir. Üst orta gelir düzeyindeki Meksika için, bir gelişmekte olan ülke olarak, yatırımların ya da borçlanmanın kamu harcamasına dönüşmesi ile kişi başı gelir arttığı düşünülebilir. Öte yandan, yüksek gelir grubunda yer alan Fransa, Güney Kore ve Kanada'da ise kişi başı gelir artışları vergileri ve bunların ise muhtemelen harcamaları tetiklemekte olduğu değerlendirilebilir. Ancak Ek 1 hatırlandığında, bu durum tam tersi yönde de düşünülebilir. Meksika'da verimsiz harcamalar arttıkça kişi başı GSYiH artış hızında düşüşler söz konusu olurken; gelişmiş üç ekonomi olan Fransa, Güney Kore ve Kanada'da kişi başı gelir arttıkça kamu harcamalarının büyük toplam içerisindeki payı küçülmektedir.

Tablonun kamu kaynakları ayağına bakıldığında ise Finlandiya, İsveç ve Meksika'da kamu gelirlerinin kişi başı gelirin nedeni olduğu görülmektedir. Ek 1'deki kuvvetli simetrik benzeşme düşünülerek değerlendirildiğinde, bu ilişkinin de ters yönlü olması olasıdır. Buna karşın İspanya, İsveç, Kanada ve Portekiz'de kişi başı gelirdeki artışlar bize kamu gelirinin belirleyici bir unsur olduğunu düşündürtmektedir. Bir önceki tablodakine benzer şekilde bir tutarlılık analizi yapılmak istenirse; Meksika, Kanada ve İsveç'te bu türden bir ilişki söz konusu gibidir. Meksika'da hem kamu gelirleri hem de harcamaları kişi başı gelir artışlarının nedeni olarak göze çarpmaktadır. Diğer taraftan, tıpkı Tablo 2'deki gibi Tablo 3'te de Kanada'da kişi başı GSYiH artışlarının hem kamu gelirlerini hem de giderlerini etkilediği görülmektedir. İsveç'te ise hem kamu gelirleri kişi başı GSYiH'in hem de kişi başı gelir yüzde artış değerleri kamu kaynaklarının bir nedeni olarak karşımıza çıkmaktadır.

Tablo 4. KHARC ile KGEL Arası İstatistiksel İlişkiye Dair Bootstrap Panel Nedensellik Sonuçları

\begin{tabular}{|c|c|c|c|c|c|c|c|c|}
\hline \multirow[b]{3}{*}{ Ülkeler } & \multicolumn{4}{|c|}{$\mathrm{H}_{0}:$ KHARC, KGEL'in nedeni değildir } & \multicolumn{4}{|c|}{$\mathbf{H}_{0}:$ KGEL, KHARC'ın nedeni değildir } \\
\hline & \multirow[b]{2}{*}{ İstatistik } & \multicolumn{3}{|c|}{ Bootstrap Kritik Değerleri } & \multirow[b]{2}{*}{ İstatistik } & \multicolumn{3}{|c|}{ Bootstrap Kritik Değerleri } \\
\hline & & \%1 & $\% 5$ & $\% 10$ & & \%1 & $\% 5$ & $\% 10$ \\
\hline$A B D$ & 67,303 & 430,059 & 297,106 & 227,641 & 30,794 & 394,604 & 246,048 & 185,373 \\
\hline Almanya & 9,104 & 388,427 & 251,997 & 193,132 & 26,313 & 266,39 & 148,273 & 111,883 \\
\hline Avustralya & $125,142 *$ & 237,954 & 142,207 & 105,169 & 10,592 & 178,093 & 106,184 & 75,138 \\
\hline Avusturya & 34,104 & 346,338 & 218,205 & 163,525 & 1,403 & 328,69 & 194,598 & 141,875 \\
\hline Belçika & 17,609 & 420,679 & 285,173 & 217,793 & 0,091 & 363,469 & 221,277 & 164,202 \\
\hline Birleşik Krallık & $179,740 *$ & 360,132 & 238,753 & 179,213 & 119,708 & 355,393 & 220,797 & 167,372 \\
\hline Finlandiya & 34,88 & 409,817 & 254,454 & 189,678 & 8,979 & 312,332 & 189,311 & 137,303 \\
\hline Fransa & 0,008 & 341,919 & 216,305 & 166,007 & 25,335 & 169,287 & 96,304 & 67,746 \\
\hline Güney Afrika & 47,033 & 436,276 & 256,965 & 197,176 & 4,23 & 223,928 & 122 & 88,74 \\
\hline Güney Kore & 11,111 & 907,52 & 588,123 & 458,804 & 15,62 & 965,361 & 595,684 & 454,1 \\
\hline Hollanda & 0,796 & 269,319 & 159,646 & 118,703 & 28,156 & 175,511 & 107,406 & 76,521 \\
\hline İrlanda & 41,274 & 460,306 & 296,314 & 229,626 & 1,042 & 342,698 & 224,684 & 174,422 \\
\hline İspanya & $312,175^{* *}$ & 433,04 & 293,323 & 225,756 & $99,133 *$ & 196,578 & 110,69 & 79,443 \\
\hline İsrail & 66,63 & 644,851 & 439,04 & 333,953 & 1,598 & 735,823 & 487,483 & 392,321 \\
\hline İsveç & $322,403 * *$ & 529,768 & 290,022 & 223,769 & 29,475 & 211,054 & 118,368 & 79,862 \\
\hline İtalya & 38,347 & 810,716 & 531,154 & 408,814 & 0,642 & 804,709 & 526,999 & 410,159 \\
\hline Japonya & 27,863 & 1056,476 & 664,391 & 517,975 & 0,145 & 1126,819 & 664,994 & 495,051 \\
\hline Kanada & 79,644 & 307,865 & 191,125 & 144,964 & 2,971 & 209,515 & 123,329 & 87,499 \\
\hline Meksika & 0,208 & 773,821 & 505,578 & 401,04 & 64,462 & 793,31 & 504,759 & 396,777 \\
\hline Portekiz & 108,304 & 389,095 & 253,643 & 193,927 & 52,787 & 181,968 & 106,7 & 72,286 \\
\hline Türkiye & $206,983 *$ & 366,736 & 247,817 & 187,887 & 52,371 & 288,112 & 184,343 & 137,668 \\
\hline Yunanistan & 43,547 & 374,271 & 228,864 & 173,119 & 6,979 & 342,303 & 209,389 & 157,44 \\
\hline
\end{tabular}

Not: ${ }^{*},{ }^{* *}$, ve ${ }^{* * *}$ sırası ile \%10, \%5 ve \%1 anlamlılık seviyesinde $H_{0}$ hipotezinin reddedildiği anlamına gelmektedir. Bootstrap kritik değerleri 10000 tekrarlı dağılımdan elde edilmiştir. Uygun gecikme Schwarz-Bayesian bilgi kriterine göre belirlenmiştir. Maksimum gecikme sayısı 4'tür. 
Tablo 4'te kamu harcamalarının ve gelirlerinin kendi aralarındaki etkileşimine yer verilmiştir. Kolaylıkla gözlemlenebileceği üzere, anlamlı istatistiki ilişkiler önemli ölçüde "harcama-vergi" hipotezini desteklemektedir. Teorik kısımda değinilen Roberts (1978) ile Peacock ve Wiseman (1979) tarafından ileri sürülen ve Barro'nun (1979) da benzer sonuçlarla desteklediği bu hipotez, kamu harcamalarını finanse etmek için giderek artan oranlarda vergilere başvurulacağını savunmaktadır. Örneklem içerisinde; Avustralya, Birleşik Krallık (İngiltere, Galler, İskoçya ve Kuzey İrlanda), İsveç ve Türkiye söz konusu bu sıçrama tezini destekler sonuç vermişlerdir. Burada istisnai durumu sergileyen ülke ise İspanya olmuştur. İspanya, kamu gelirleri ve giderlerinin her ikisinin de birbirini etkilediği savına dayanan; Musgrave (1966) ile Meltzer ve Richard (1981) tarafından öne sürülen "mali senkronizasyon" ya da "mali uyum" hipotezini desteklemektedir.

Tablo 5. Tüm Modeller İtibariyle Panel Nedenselliğin Yönüne Dair Özet Tablo

\begin{tabular}{|c|c|c|c|c|c|c|c|c|c|c|}
\hline \multirow{2}{*}{$\begin{array}{ll} & \text { Ülkeler } \\
A B D & \\
\end{array}$} & \multicolumn{2}{|c|}{ KHARC/GSYH } & \multicolumn{2}{|c|}{ KGEL/GSYH } & \multicolumn{2}{|c|}{ KHARC/KBGSYH } & \multicolumn{2}{|c|}{ KGEL/KBGSYH } & \multicolumn{2}{|c|}{ KHARC/KGEL } \\
\hline & & & & & & & & & & \\
\hline \multicolumn{11}{|l|}{ ALMANYA } \\
\hline AVUSTRALYA & & & & & & & & & $\rightarrow$ & \\
\hline \multicolumn{11}{|l|}{ AVUSTURYA } \\
\hline \multicolumn{11}{|l|}{ BELÇiKA } \\
\hline BirLeŞiK KRALLIK & & & & & & & & & $\rightarrow$ & \\
\hline FiNLANDIYA & & & & & & & $\rightarrow$ & & & \\
\hline FRANSA & & $\leftarrow$ & & & & $\leftarrow$ & & & & \\
\hline \multicolumn{11}{|l|}{ GÜNEY AfRIKA } \\
\hline GÜNEY KORE & & & & & & $\leftarrow$ & & & & \\
\hline HOLLANDA & $\rightarrow$ & & $\rightarrow$ & & & & & & & \\
\hline \multicolumn{11}{|l|}{ İ́LANDA } \\
\hline İSPANYA & & & & & & & & $\leftarrow$ & $\rightarrow$ & $\leftarrow$ \\
\hline \multicolumn{11}{|l|}{ İsRail } \\
\hline İSVEÇ & & & $\rightarrow$ & & & & $\rightarrow$ & $\leftarrow$ & $\rightarrow$ & \\
\hline \multicolumn{11}{|l|}{ İTALYA } \\
\hline \multicolumn{11}{|l|}{ JAPONYA } \\
\hline KANADA & & $\leftarrow$ & & $\leftarrow$ & & $\leftarrow$ & & $\leftarrow$ & & \\
\hline MEKSIKA & & & $\rightarrow$ & & $\rightarrow$ & & $\rightarrow$ & & & \\
\hline PORTEKIZ & & & & $\leftarrow$ & & & & $\leftarrow$ & & \\
\hline TÜRKIYE & & & & & & & & & $\rightarrow$ & \\
\hline YUNANISTAN & & & & & & & & & & \\
\hline
\end{tabular}

Tüm ampirik analizleri bir araya getiren Tablo 5, sonuçların bir bütün olarak yorumlanması açısından önemlidir. Bu şekilde yakalanan bütüncüllük sayesinde görece toplu bir değerlendirme yapılabilmesi de mümkün olacaktır. Bu doğrultuda tablo incelendiğinde, en fazla etkileşimin kamu harcamalarından kamu gelirlerine doğru olduğu göze çarpmaktadır. Bunu, kişi başı GSYiH'in kamu gelirlerinin belirleyicisi olduğu istatistiksel anlamlı sonuçlar takip etmektedir. Yine, üçer adet anlamlılık sütunlarıyla kamu gelirlerinden GSYiH'e, kişi başı gelirden kamu harcamalarına ve kamu gelirlerinden kişi başı GSYiH değişim düzeylerine doğru güçlü ve anlamlı linklerin bulunduğu savunulabilir. GSYiH ile kamu gelir ve giderleri arasında yapılan analizlerde 8, kişi başı gelir ile yapılan analizlerde ise 11 ilişkiyle karşılaşılmış olması da tablodaki bir diğer çarpıcı bulgudur. Belki bu anlamda kamu gelir ve harcamalarının, hanehalkının bütçesiyle ekonominin geneline kıyasla daha fazla ilintili olduğu değerlendirmesi yapılması da yanlış olmayacaktır. İsveç, Kanada, İspanya ve Meksika çalışmada en fazla istatistiki anlamlılıkların yakalandığı ülkeler olmuştur. Bu ülkeler kararı sonuçlar açısından değerlendirildiğinde, özellikle Kanada ve Meksika ön planda göze çarpmaktadır. Kanada'da gerek GSYiH gerekse de kişi başı gelirlerin kamu gelir ve giderleri üzerindeki nedensellik etkisi ve yönü (en azından 1985-2017 dönem aralığı için) oldukça kuvvetli bir biçimde kendisini göstermektedir. Meksika'da ise hem kamu gelirleri hem de giderlerindeki artış ve azalışlar, GSYiH ile kişi başı geliri etkilemekte ve bu değişkende oluşacak farklılaşmaların nedenini oluşturmaktadır. 


\section{Sonuç ve Değerlendirme}

Bu çalışmada, 1985-2017 dönem aralığı için 22 üst ve üst orta gelirli ülke -ki bu ülkeler aynı zamanda OECD üye ve/veya paydaşıdır- bootstrap panel Granger nedensellik sınamasına tabi tutulmuştur. Kamu gelir ve giderlerinin iki farklı gayrisafi yurtiçi hâsıla değişkeni (ekonomik büyüme yıllık değişim oranları, kişi başı gelir yüzde değişimleri) ile olan etkileşimi ve kendi aralarındaki ilişkileri kuramsal ve deneysel bir bütüncüllük içerisinde ele alınmaya çalışılmıştır. Ampirik analiz sonuçlarına göre, genel bir yorumla (Tablo 5) özellikle kamu gelirleri ile GSYiH arasında (kamu harcamalarına kıyasla) daha kuvvetli bir etkileşim olduğu; öte yandan, kamu harcamaları ile de gelirleri arasında benzer bir nedensellik ilişkisi olduğu görülmüştür.

Yine çalışmada, özellikle Hollanda, İspanya, İsveç, Kanada ve Meksika için önemli bulgular edinilmiştir. Yönleri ve değişkenleri farklı olmakla beraber, bu ülkeler için yapılan analizlerde birden fazla sayıda istatistiki bağıntıya ulaşıımıştır. Sonuçlar bize, en azından genel anlamda kamu gelir ve giderleriyle GSYiH ve kişi başı gelir değişimleri arasında uzun dönemli bir nedensellik ilişkisi olabileceğini göstermektedir. Bir diğer deyişle, gelişmiş ve gelişmekte olan ülkeler yapısal veya konjonktürel olarak birbirinden farklılaştırılabilirse de maliye politikası araçlarıyla ekonomik büyümeyi tetikleyebilme veya frenleyebilme yönleriyle kimi noktalarda benzeşebilmektedirler. Politika yapıcıların, bu anlamda, uzun dönemli iktisat ve maliye politikası amaçlarına yönelik olarak söz konusu araçları kullanırken motive edici veya kısıtlayıcı tarafları da dikkate alması gerektiği savunulabilir. Öte yandan çalışmadan Türkiye özelinde bir çıkarsama yapılmak istenirse, 1985-2017 yılları arası veri seti ile yapılan analizler çerçevesinde; ne kamu harcamalarının ne de gelirlerinin çeyrek asrı aşkın süre zarfında her iki bağımlı değişkenle de (GSYH, KBGSYH) istatistiksel bir etkileşim içerisinde bulunmadığı söylenebilir. Buna karşın, ilgi çekici bir nokta olarak en azından 33 yıllık bu süreçte, süregelen kamu harcamalarının kamu gelirlerinin nedeni olabileceği istatistiksel olarak tespit edilmiştir. Bu durum, Roberts (1978), Peacock ve Wiseman (1979) ve Barro'nun (1979) görüşleriyle uyumlu olan "harcama-vergi" hipotezinin Avustralya, Birleşik Krallık, İsveç ile birlikte Türkiye için de geçerli olabileceğini düşündürmektedir. En azından ampirik modellemeler nihayetinde ulaşılan sonuç bu şekildedir.

Çalışmaya konu temel iki maliye politikası aracından özellikle kamu harcamalarının, yönü itibariyle kamu gelirlerini azımsanamayacak biçimde etkilediği; benzer şekilde, GSYiH ve kişi başı GSYiH değerlerinin de her iki mali aracı farklı şekillerde etkileyebildiği ve etkilenebildiği Tablo 5'te görülebilmektedir. Söz konusu karmaşık nedensellik ilişkileri çerçevesinde, gelişmiş bir ülke için ekonomik büyüme, gelişmekte olan için ise iktisadi kalkınma hedeflerine ulaşılmasında politika yapıcılar açısından uygulanabilecek 'tek tip' bir reçete bulunmadığı değerlendirmesi yapılabilir. Yine de özellikle kamu harcamalarının kamu gelirlerinin nedenselliğini açıklamada görece anlamlı olması ve kamu gelirleri ile de GSYiH ve kişi başı gelir seviyeleri arasında yoğun istatistiksel ilişkilerle karşılaşılmış olması nedeniyle, maliye politikalarında harcama yönlü yönelimlerin üretken alanlara kaydırıması halinde ekonomide pozitif etkilere yol açılabileceği savunulabilir. Bu çıkarsama ele alınan her bir ülke ve her yıl için genel geçer bir doğru olarak kabul edilemese dahi, ele alınan tüm ülkeler kendilerine uygun yol haritasını benzer şekillerde belirleyebileceklerdir. Dolayısıyla, tespit edilen uzun dönemli ve kronikleşmiş sorunların (tasarruf, yatırım, borç yapısı, eğitim, sağlık, altyapı, savunma ve benzeri alanlardaki eksiklikler gibi) çözümüne yönelik politikalar geliştirilirken ülkenin kendine has gerçekliklerinin de bu genellemeler ile birlikte göz önünde tutulması yerinde olacaktır.

\section{Son Notlar}

1. Bu durumun uzun dönemli bir görünümüne (ve belki de ispatına) örnek teşkil etmesi amacıyla 1985-2017 yılları dönem aralığı için incelenecek 22 ülkenin kamu gelir ve giderleri ile GSYiH ve kişi başı GSYiH değerlerinin ilgili yıl ortalamaları EK 1'de sunulmaktadır. Özellikle kamu harcamaları ile GSYiH ve kişi başı GSYiH değerleri arasında yıllar itibariyle yaşanan zıt yönlü değişimler dikkat çekicidir.

2. "The long run is a misleading guide to current affairs. In the long run we are all dead" (Keynes, 1924: 80). Keynes bu sözü ile kısa dönemli analizin önemini vurgulamakta ve ekonomistler tarafindan uzun dönemde bir dengeye ulaşılacağının söylenmesinin kolaycılık olacağını (bugünün sorunlarını çözemediğini) savunmaktadır.

3. Keynes'e göre kamu harcamaları, özel yatırımcılarca kapsanmayan tam kamusal veya yarı kamusal mal ve hizmetlere (altyapı, sosyal güvenlik, savunma, adalet, eğitim, sağılı vb.) yönlendirilebildiği ölçüde klasik iktisadi 
görüş savunucularının "Dışlama Etkisi (Crowding Out)" dediği olguyu ortadan kaldırabilecektir. Devletler maliye politikası araçlarıyla dışlama değil ekonomide tamamlayııılık görevi üstlenmiş olacaktır ve bu ise nihai olarak yeni girişim alanlarının doğmasına (Crowding In) neden olur.

4. Onlara göre, vergilerin azaltılması aslen daha fazla kamu harcaması yapılabilmesine olanak tanımaktadır çünkü böyle bir durumda kamusal mal ve hizmet sunumu bir önceki duruma göre (ex-ante) çok daha ucuz hale gelmiş olacaktır.

5. PIIGS ülkeleri; Portekiz, Irlanda, Italya, Yunanistan ve Ispanya'dır. Bu ülkeler, ilk olarak 2008 Küresel Krizi sonrasında yüksek borçlanma değerleri ve kamu dengesindeki bozulmalarla dikkat çekmiştir. Mali yazında bu ülkelerin kimi zaman "PIIGGS" olarak adlandırılarak Birleşik Kralıı'ın da söz konusu kısaltmaya dâhil edilebildiği görülmektedir.

6. Çalışmada, -alternatif yöntem ve açıklamalar da dikkate alınarak-, kuramsal altyapısına yukarıda değinilen, yatay kesit bağımlılığı ve heterojenliği göz önünde bulunduran, Kónya (2006) tarafından önerilen Bootstrap Panel Nedensellik Yaklaşımı kullanılması planlanmıştır. Bu yöntem, sözel bir ifadeyle, ülkeye özgü bootstrap kritik değerlerinden yola çıkarak her bir örneklem için -ülkeler arası olası eşzamanlı korelasyonu da göz önünde bulundurarak-, Granger panel nedenselliği test etmeye olanak sağlamaktadır.

7. Değişkenler arasındaki ilişkiyi belirleyen faktörlere dair gözlemler, alt model/paneller vasıtasıyla sınanarak analizler sağlamlaştırılmaya çalışılmıştır. Eksiksiz veri seti ile oluşturulan panel veri regresyonlarının GAUSS programı vasıtasıyla tahmini planlanmıştır. Kullanılan bootstrap panel Granger nedensellik analizinin Gauss program prosedürü için bkz.; Kónya, L. (2006) ve kod için bkz.; Kar, M., Nazlıoğlu, ş. ve Ağır, H. (2011) ve Menyah, K., Nazlıoğlu, S. ve Wolde-Rufael, Y. (2014).

8. Bootstrap panel nedensellik testine temel oluşturan ön testlerin teorik özeti Ek 2'de, sonuçları ise Ek 3'te yer almaktadır.

9. Kamu gelirleri ve giderleri ile ekonomik büyüme ve kişi başı GSYiH arası istatistiksel ilişkiyi irdeleyecek olan bu çalışma da aynı format dâhilinde ve değinilen dört temel hipotezin sınanması doğrultusunda yürütülecektir.

10. Yatay kesit bağımlılığına ilişkin bulgular, 80'lerden günümüze değin süregelen değişimlerin sadece bir ülke ile sınırı kalmadığını, gelişmelerin diğer ülkeleri de etkileyebildiğini ortaya koymaktadır. Heterojenite ile ortaya çıkan durum ise her ülke için farklı nedensellik dinamiklerinin bulunabileceğini göstermektedir. Sonuç olarak, uygulama modelinde yatay kesit bağımlıı̆ının bulunması yanı sıra eğim katsayılarının heterojen olması her iki durumu da göz önünde bulunduran bootstrap panel nedensellik analizinin kullanılmasını gerekli kılmaktadır.

\section{Kaynaklar}

Adkisson, R. V., \& Mohammed, M. (2014). Tax structure and state economic growth during the Great Recession. The Social Science Journal, 51(2014), 79-89.

Afonso, A., \& Rault, C. (2009). Spend and tax: A panel data investigation for the EU. Economics Bulletin, 29(4), 25422548.

Amir, H., Asafu-Adjaye, J., \& Ducpham, T. (2013). The impact of the Indonesian income tax reform: A CGE analysis. Economic Modelling, 31(2013), 492-501.

Arellano, M. (2003). Panel data econometrics. New York: Oxford University Press.

Asteriou, D., \& Hall, S. G. (2007). Applied econometrics: A modern approach using e-views and microfit. New York: Palgrave Macmillan.

Baghestani, H., \& McNown R. (1994). Do Revenues or expenditures respond to budgetary disequilibria? Southern Economic Journal, 60(2), 311-322.

Baltagi, B. H. (2001). Econometric analysis of panel data (2nd Ed.). Chichester: John Wiley \& Sons, Ltd.

Barro, R. J. (1979). On the determination of the public debt. Journal of Political Economy, 81, 940-971.

Barro, R. J. (1991). Economic growth in a cross section of countries. Quarterly Journal of Economics, 106(2), 407-443.

Bolat, S. (2014). The relationship between government revenues and expenditures: Bootstrap panel granger causality analysis on European countries. Economic Research Guardian, 4(2), 2-17.

Breitung, J. (2005). A parametric approach to the estimation of cointegration vectors in panel data. Econometric Reviews, 24, 151-173.

Breusch, T., \& Pagan, A. (1980). The Lagrange multiplier test and its application to model specifications in econometrics. Reviews of Economics Studies, 47, 239-253. 
Buchanan, J. M., \& Wagner, R. E. (1977). Democracy in deficit: The political legacy of Lord Keynes. New York: Academic Press.

Bujang, I., Abd, T., \& Ahmad, I. (2013). Tax structure and economic indicators in developing and high-income OECD countries: Panel cointegration analysis. Procedia Economics and Finance, 7(2013), 164-173.

Chang, T., \& Chang, G. (2009). Revisiting the government revenue-expenditure nexus: Evidence from 15 OECD countries based on the panel data approach. Czech Journal of Economics and Finance, 59, 165-172.

Chang, T., Liu, W.R., \& Caudill, S.B. (2002). Tax-and-spend, spend-and-tax, or fiscal synchronization: New evidence for ten countries. Applied Economics, 34(12), 1553-1561.

Cheng, B.S. (1999). Causality between taxes and expenditures: Evidence from Latin American countries. Journal of Economics and Finance, 23(2), 184-192.

Chu, H. P., Chang, T., \& Sagafi-nejad, T. (2016). Globalization and economic growth revisited: A bootstrap panel causality test. Contemporary Economic and Management Studies in Asia and Africa, Cyrus Chronicle Journal, 1(1), 30-44.

Cooray, A. (2009). Government expenditure, governance and economic growth. Comparative Economic Studies, 51(2009), 401-418.

Dünya Bankası (2018). http://databank.worldbank.org/data/reports.aspx?source=world-development-indicators

Dzhumashev, R. (2014). Corruption and growth: The role of governance, public spending, and economic development. Economic Modelling, 37, 2013-2015.

Easterly, W., \& Rebelo, S. (1993). Fiscal policy and economic growth. Journal of Monetary Economics, 32, 417-458.

Friedman, M. (1978). The limitations of tax limitation. Policy Review, 5(78), 7-14.

Granger, C. W. J. (1969). Investigating causal relations by econometric models and cross-spectral methods. Econometrica, 37(3), 424-438.

Granger, C. W. J. (2003). Some aspects of causal relationships. Journal of Econometrics, 112, 69-71.

Greene, W. H. (2003). Econometric analysis (5th Ed.). London: Prentice Hall.

Hacker, R. S., \& Hatemi-j, A. (2006). Tests for causality between integrated variables using asymptotic and bootstrap distributions: Theory and application. Applied Economics, 38(13), 1489-1500.

Hitiris, T., \& Posnett, J. (1992). The determinants and effects of health expenditure in developed countries. Journal of Health Economics, 11(2), 173-181.

Hurlin, C. (2008). Testing for granger non-causality in heterogeneous panels, Mimeo. Department of Economics: University of Orleans.

IMF (2018). Fiscal monitor \& global debt database and world economic outlook, https://www.imf.org/en/Data

Kar, M., Nazlıoğlu, Ş., \& Ağır, H. (2011). Financial development and economic growth nexus in the MENA countries: Bootstrap panel granger causality analysis. Economic Modelling, 28(1-2), 685-693.

Keynes, J. M. (1924). A tract on monetary reform. London: Macmillan.

Kneller, R., Bleaney, M. F., \& Gemmell, N. (1999). Fiscal policy and growth: Evidence from OECD countries. Journal of Public Economics, 74(2), 171-190.

Konukcu-Önal, D., \& Tosun, A.N. (2008). Government revenue-expenditure nexus: Evidence from several transitional economies. Economic Annals, 53, 145-156.

Kónya, L. (2006). Exports and growth: Granger causality analysis on OECD countries with a panel data approach. Economic Modelling, 23(6), 978-992.

Lee, Y., \& Gordon, R. H. (2005). Tax structure and economic growth. Journal of Public Economics, 89(2005), 1027-1043.

Mehrara, M., Pahlavani, M., \& Elyasi, Y. (2011). Government revenue and government expenditure nexus in Asian countries: Panel cointegration and causality. International Journal of Business and Social Science, 2, $199-207$.

Meltzer, A. H., \& Richard S. F. (1981). A rational theory of the size of government. Journal of Political Economy, 89(5), 914-927.

Menyah, K., Nazlıoğlu, S., \& Wolde-Rufael, Y. (2014). Financial development, trade openness and economic growth in African countries: New insights from a panel causality approach. Economic Modelling, 37, 386-394.

Musgrave, R. (1966). Principles of budget determination. In H. Cameron, W. Henderson (Ed.), Public Finance: Selected Readings, 15-27, New York: Random House.

Mutascu, M. (2015). A bootstrap panel granger causality analysis of government revenues and expenditures in the PIIGS countries, Economics Bulletin, 35(3), 2000-2004. 
Mutascu, M. (2016). Government revenues and expenditures in the east european economies: A bootstrap panel granger causality approach. Eastern European Economics, 54(6), 489-502.

Narayan, P.K., \& Narayan, S. (2006). Government revenue and government expenditure nexus: Evidence from developing countries. Applied Economics, 38(3), 285-291.

Nazlıoğlu, Ş., Lebe, F., \& Kayhan, S. (2011). Nuclear energy consumption and economic growth in OECD countries: Crosssectionally dependent heterogeneous panel causality analysis. Energy Policy, 39(10), 6615-6621.

OECD (2018). OECD Statistics (oecd.stat), http://stats.oecd.org/

Ojede, A., \& Yamarik, S. (2012). Tax policy and state economic growth: The long-run and short-run of it. Economics Letters, 116(2), 161-165.

Owoye, O. (1995). The causal relationship between taxes and expenditures in the G7 countries: Cointegration and error correction models. Applied Economics Letters, 2(1), 19-22.

Paleologou, S. M. (2013). Asymmetrics in the revenue-expenditure nexus: A tale of three countries. Economic Modelling, 30(C), 52-60.

Payne, J. (1998). The tax-spend debate: Time series evidence from state budgets. Public Choice, 95(3-4), 307-320.

Peacock, A. T., \& Wiseman, J. (1979). Approaches to the analysis of government expenditure growth. Public Finance Quarterly, 7(1), 3-23.

Pesaran, M. H. (2004). General diagnostic tests for cross section dependence in panels. CESifo WP, 1229, IZA Discussion Paper, 1240.

Pesaran, M. H., Ullah, A., \& Yamagata, T. (2008). A Bias-Adjusted LM Test of Error Cross-section Independence. Econometrics Journal, 11(1), 105-127.

Pesaran, M. H., \& Yamagata, T. (2008). Testing slope homogeneity in large panels. Journal of Econometrics, 142(1), 5093.

Roberts, P. C. (1978). Idealism in public choice theory. Journal of Monetary Economics, 4(3), 603-615.

Smith, A. (1776). An inquiry into the nature and causes of the wealth of nations. www.era.lib.ed.ac.uk/handle/1842/1455

Shastri, S., Giri, A.K., \& Mohapatra, G. (2017). budget deficit sustainability and revenue expenditure linkages in major South Asian economies. Eurasian Journal of Business and Economics, 10(19), 37-59.

Solow, R. M. (1956). A contribution to the theory of economic growth. The Quarterly Journal of Economics, 70(1), 6594.

Swamy, P.A.V.B. (1970). Efficient inference in a random coefficient regression model. Econometrica, 38(2), $311-323$.

T.C. Hazine ve Maliye Bakanlığı (2018). https://www.treasury.gov.tr/public finance-statistics

Wagner, A. (1883). Three extracts on public finance. In R. A. Musgrave ve A. T. Peacock (eds) (1958), Classics in the theory of public finance, London: Macmillan.

Wagner, R. E. (1976). Revenue structure, fiscal ıllusion, and budgetary choice. Public Choice, 25(1), 45-61.

Westerlund, J., Mahdavi, S., \& Firoozi, F. (2011). The tax-spending nexus: Evidence from a panel of US state-local governments. Economic Modelling, 28(3), 885-890.

Wildavsky, A. (1988). The new politics of the budgetary process. Glenview III. Scott, Foresman \& Co.

Zellner, A. (1962). An efficiency method of estimating seemingly unrelated regression equations and tests for aggregation bias. Journal of the American Statistical Association, 57, 348-368. 


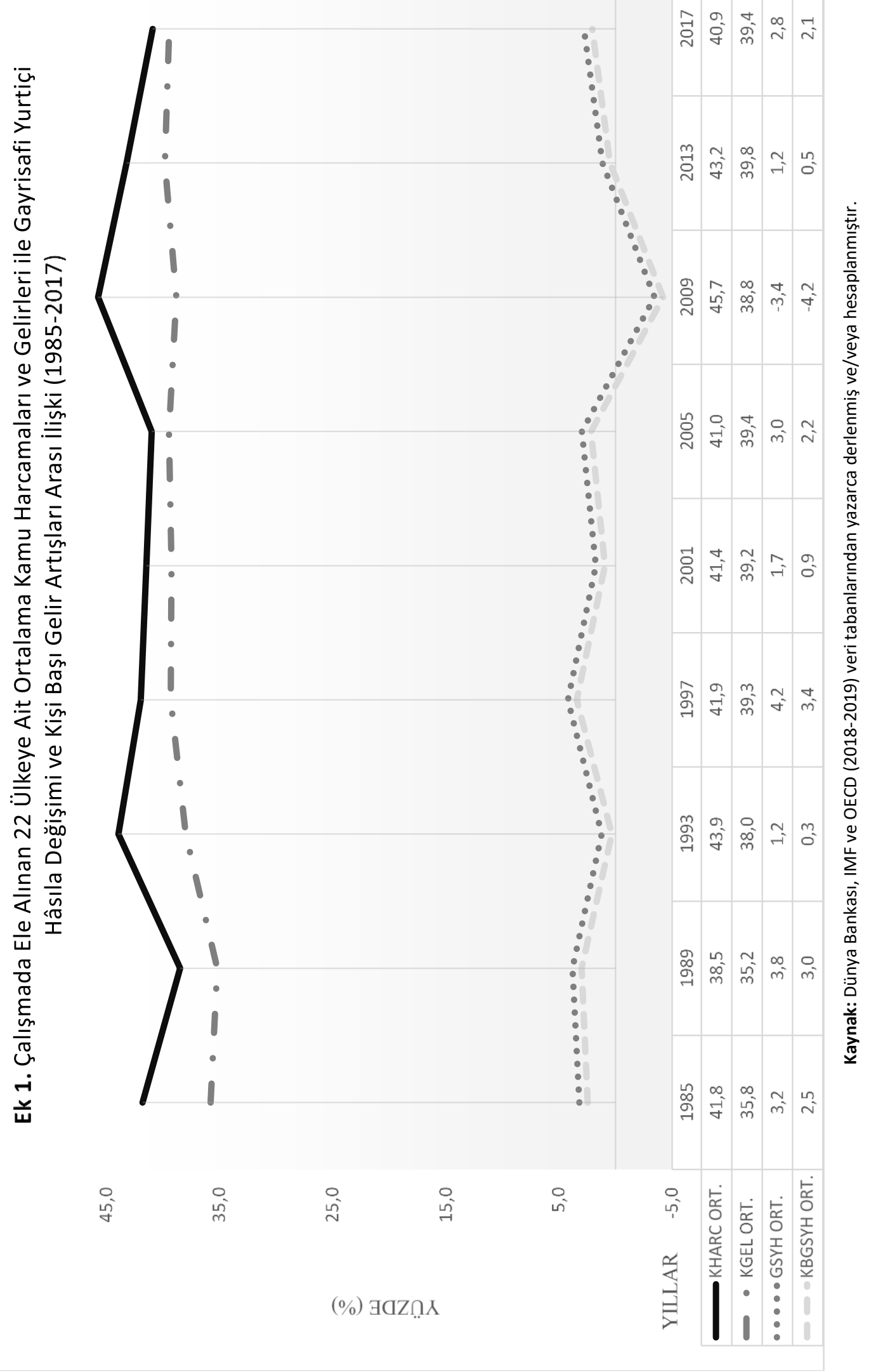




\section{Ek 2. Bootstrap Panel Granger Nedensellik Testine Temel Oluşturan Ön Testlerin Teorik Özeti}

\section{- Yatay Kesit Bağımlıı̆ı Testleri}

Analizlerde, yatay kesit bağımlılığı bulunup bulunmadığının tespiti için üç ayrı test yapılması planlanmaktadır: i) Breusch ve Pagan (1980) Lagrange çarpanı test istatistiği, ii) Pesaran (2004) yatay kesit bağımlılı̆ı testi, iii) Pesaran, Ullah ve Yamagata (2008) tarafından önceki testlerin geliştirilmesi uyarlanan ve çift yönlü korelasyon katsayılarına dayanan yatay kesit bağımlıık testi. Testlerden ilki olan Breusch ve Pagan (1980) tarafından önerilen LM tahmincisine göre, panel veri analizine konu model şu şekilde oluşturulmaktadır:

$$
Y_{i t}=\alpha_{i}+\beta_{i} X_{i t}+\mu_{i t}
$$

$$
\mathrm{i}=1,2,3, \ldots \mathrm{N} ; \mathrm{t}=1,2,3, \ldots \mathrm{T}
$$

Denklemde i yatay kesit boyutunu; $t$ zaman boyutunu; $X_{\text {it }}$ kx1 açıklayıcı değişkenler vektörü, $\alpha i$ ve $\beta i$ ülkeler arası farklılaşan kesişim bölgelerini ve eğim katsayılarını göstermektedir. LM testinde, yatay kesit bağımlılı̆ının bulunmadığı boş hipotez, tüm $t$ değerleri için $\mathrm{H}_{0}$ : $\operatorname{Cov}\left(\mu_{\mathrm{it}}, \mu_{\mathrm{jt}}\right)=0$ ve $\mathrm{i} \neq \mathrm{j}$ veya alternatif hipotez olan $\mathrm{H}_{1}$ : $\operatorname{Cov}\left(\mu_{\mathrm{it}}, \mu_{\mathrm{jt}}\right) \neq 0$ ve en az bir yatay kesitin varlığına dair $\mathrm{i} \neq \mathrm{j}$ denklemlerini doğrulayacak şekilde teste tabi tutulmaktadır. Boş hipotezi test etmek için Lagrange çarpan test istatistiği Breusch ve Pagan (1980) tarafından aşağıdaki şekilde sunulmaktadır $\left(\mathrm{CD}_{\mathrm{BP}}\right)$ :

$$
C D_{B P}=\mathrm{T} \sum_{i=1}^{N-1} \sum_{j=i+1}^{N} \hat{\rho}_{i j}^{2}
$$

Yukarıdaki denklikte $\hat{\rho}_{\mathrm{ij}}^{2}$, bireysel EKK tahmininden elde edilen hata terimleri arasındaki tahmin edilmiş korelasyon katsayılarını göstermektedir. $\mathrm{H}_{0}$ hipotezi altında, sabit yatay kesit sayısı (N: sabit) ve zaman periyodu sonsuza giderken $(T \rightarrow \infty) C_{B P}$ test istatistiği $\mathrm{N}(\mathrm{N}-1) / 2$ serbestlik derecesinde ki-kare asimptotik dağılımına sahiptir (Breusch ve Pagan, 1980). Öte yandan, yatay kesit sayısının artması testin uygulanmasında sorunlarla karşılaşılmakta ve $\mathrm{N} \rightarrow \infty$ durumunda $\mathrm{CD}_{\mathrm{BP}}$ testinin uygulanamayacağı belirtilmektedir. Pesaran (2004) bu durumun üstesinden gelebilmek için $\mathrm{CD}_{\llcorner\mathrm{LM}}$ test istatistiğini geliştirmiştir:

$$
C D_{L M}=\sqrt{\frac{1}{N(N-1)}} \sum_{i=1}^{N-1} \sum_{j=i+1}^{N}\left(T \hat{\rho}_{i j}^{2}-1\right)
$$

$\mathrm{CD}_{\llcorner M}$ test istatistiği, büyük $\mathrm{T}$ değerleri için normal dağılıma sahipken yine de $\mathrm{T}>\mathrm{N}$ şartı aranmaktadır. Pesaran (2004), aynı makalede, böyle bir şartın aranmadığı CD testini ayrıca oluşturmuştur. Bu doğrultuda, $T$ $\rightarrow \infty$ ve $\mathrm{N} \rightarrow \infty$ durumlarında $\mathrm{N}>\mathrm{T}$ ya da $\mathrm{T}>\mathrm{N}$ gerçekleşmelerinin her ikisi için de $\mathrm{CD}$ istatistiği asimptotik standart normal dağılıma sahiptir. CD istatistiği aşağıdaki gibi gösterilmektedir:

$$
C D=\sqrt{\frac{2 T}{N(N-1)}} \sum_{i=1}^{N-1} \sum_{j=i+1}^{N} \hat{\rho}_{i j}
$$

Yine, sonraki dönemde Pesaran vd. (2008) yapmış oldukları çalışmada, hata terimi için uit $=\lambda i F t+\varepsilon i$ şeklinde tanımlanan ortak faktör yapısında ( $\lambda$ i: Faktör yüklemesi, Ft: Ortak faktör) faktör yüklemesi ortalamaları sıfıra girerken $\mathrm{CD}_{\mathrm{BP}}$ testinin $\mathrm{H}_{0}^{\prime}$ ' kabul etme eğiliminde olduğunu göstermiştir. Bu sorun $\mathrm{LM}_{\mathrm{adj}}$ testi ile düzeltilmiş olup

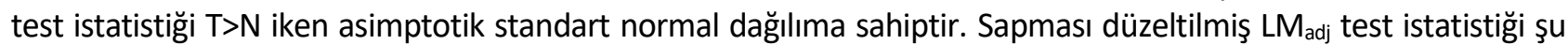
şekilde gösterilebilir:

$$
L M_{a d j}=\sqrt{\frac{2 T}{N(N-1)}} \sum_{i=1}^{N-1} \sum_{j=i+1}^{N} \hat{\rho}_{i j} \frac{(T-k) \hat{\rho}_{i j}^{2}-u_{T i j}}{\sqrt{v_{T i j}^{2}}}
$$

Denklikte yer alan $\mathrm{u}_{\mathrm{Tij}}$ ve $\mathrm{v}_{\mathrm{Tij}}^{2}$, (T-k) $\hat{\rho}_{\mathrm{ij}}^{2 \prime}$ nin kesin ortalamasını ve varyansını göstermektedir. $\mathrm{T} \rightarrow \infty$ ve $\mathrm{N} \rightarrow \infty$ durumunda yatay kesit bağımlılığı bulunmayan sıfır hipotezi koşulları altında test asimptotik standart normal dağılım sergileyecektir (Bkz.; Pesaran vd., 2008). 


\section{- Eğim Homojenite Testleri}

Incelenmesi gereken bir diğer olası problem, panel nedensellik modelinin tahmini esnasında eğim katsayılarının heterojen olup olmadığına dairdir. Parametrelerin homojen kabul edilmesi durumunda, nedensellik analizindeki ülkelere özgü farklılıkların gözden kaçırılmasına neden olmaktadır (Granger, 2003; Breitung, 2005; Nazlığlu, Lebe ve Kayhan, 2011: 6618). Böyle değerlendirildiğinde, kamu gelir ve giderleri ile ekonomik büyüme değerleri arasındaki nedenselliği belirli ülkeler ve ülke grupları için araştıran bu çalışmada, heterojeniteye ve dolayısıyla ülkelerin ihtiyari (iradi) maliye politikası seçimlerine özel önem atfetmek yerinde olacaktır. Yatay kesit boyutu göreli olarak küçük ve panel veri setindeki zaman serisine ait boyut büyükse eğim homojenitesi hipotezi Zellner (1962) SURE (Seemingly Unrelated Regression Equation) aracılı̆ı̆yla test edilebilir. Bu uygulama çatısı, özellikle yatay kesit korelasyon ve dinamiklerini otomatik olarak dikkate aldığı için ilgi çekici olsa dahi; ancak ve ancak, $N$ küçük değerlerde (5-10 civarı) iken ve T de yeterince büyük (80100 civarı) olduğunda kullanılabilmektedir. Uygulama özelinde ise kimi zaman $\mathrm{N}$ boyutu $\mathrm{T}^{\prime}$ den büyük olabilmektedir. Böyle durumlarda SURE yaklaşımı uygulanamamaktadır (Pesaran ve Yamagata, 2008: 50). Sözü edilen zayıflığı gidermek için yatay kesit sayısının zaman boyutundan daha büyük olduğu şartlarda da geçerli olacak iki farklı eğim homojenliği testi ( $\Delta$ ve $\Delta_{\text {adj }}$ ) Pesaran ve Yamagata (2008) tarafından geliştirilmiştir.

Bilindiği üzere, standart $F$ testi, bütün i değerlerinde heterojenitenin reddedildiği $H_{0}: \beta_{i}=\beta$ gibi bir denklikte veya sıfırdan farklı bir ikili eğimin bulunduğu $(i \neq j) \mathrm{H}_{1}: \beta_{\mathrm{i}} \neq \beta_{\mathrm{j}}$ şeklindeki bir denklikte boş hipotezin eğim homojenitesini ölçümlemede sıklıkla başvurulan ana yöntemdir. Ancak bu test, açıklayıcı değişkenlerin katı bir biçimde dışsal olması yanı sıra hata dağııımının da homoskedastik (eşit varyansı) yapıda olmasını gerektirmektedir. F testinde homoskedastisite varsayımını görece kolaylaştırabilmek için Swamy (1970), uygun bir havuzlanmış tahminci vasıtasıyla özgün eğim tahminlerinin dağılımlarını inceleyen eğim homojenite testi geliştirmiştir.

Pesaran ve Yamagata (2008), N sayılarının T değerlerine kıyasla görece düşük olduğu panel veri modellerinde hem $F$ testinin hem de Swamy (1970) testinin uygulanmasının yerinde olacağını vurgulamışlardır. Aynı nedenle, Swamy testini ( $\tilde{\Delta}$ test) geniş panel modellemelerine uyarlamışlardır. Hata terimlerinin normal dağıldığı, $(N, T) \rightarrow \infty$ şartını sağlayan ve $N$ ve T'nin göreli gelişme gösterdiği kısıt olmayan modellemelerde $\Delta$ testi geçerlidir. Bu varsayımlar altında, Swamy test istatistiği şu şekilde düzenlenebilir:

$$
\widetilde{S}=\sum_{i=1}^{N}\left(\hat{\beta}_{i}-\hat{\beta}_{W F E}\right)^{\prime} \frac{X_{i}^{\prime} M_{\tau} X_{i}}{\widehat{\sigma}_{i}^{2}}\left(\hat{\beta}_{i}-\hat{\beta}_{W F E}\right)
$$

Yukarıda, $\widehat{\beta}_{\mathrm{i}}$ havuzlanmış en küçük kareler (EKK) tahmincisini; $\hat{\beta}_{\mathrm{WFE}}$, [1] numaralı denkliğin ağırlıklandırılmış sabit etkiler havuzlanmış tahmincisini; $M_{\tau}$, T sırasına ait birim matrisini ve $\widehat{\sigma}_{i}^{2}$ ise $\sigma_{i}^{2 \prime}$ ye ait tahminciyi göstermektedir. Pesaran ve Yamagata (2008) bu denklik üzerinden hareket ederek bir başka formülasyon vasıtasıyla aşağıdaki standart dağılım istatistiğini elde etmişlerdir:

$$
\tilde{\Delta}=\sqrt{N}\left(\frac{N^{-1} \tilde{S}-k}{\sqrt{2 k}}\right)
$$

Buna göre, açıklayıcı değişkenlerin katı biçimde dışsal olduğu ve hata teriminin normal dağılmadığı bir durumda $\Delta$ test değeri $(N, T) \rightarrow \infty$ ve $\sqrt{\mathrm{N}} / \mathrm{T} \rightarrow \infty$ iken standart normal dağlıma sahip olacaktır. Hataların normal dağıldığı durumda ise $N$ ve T'nin birbirlerine kıyasla büyüklüğü ne düzeyde gerçekleşirse gerçekleşsin testin ortalama varyans sapmasının düzeltilmiş olan versiyonu $\left(\Delta_{\text {adj }}\right)$ asimptotik standart normal dağııım sergileyecektir. Yine Pesaran ve Yamagata (2008), hataların normal dağılım sergilediği bir durumda, $\Delta$ testinin küçük örneklem özelliklerinin aşağıdaki ortalama ve varyans sapmaları düzeltilmiş versiyonla daha iyi kavranacağını belirtmektedirler:

$$
\tilde{\Delta}_{a d j}=\sqrt{N}\left(\frac{N^{-1} \tilde{S}-E\left(\tilde{Z}_{i t}\right)}{\sqrt{\operatorname{var}\left(\tilde{Z}_{i t}\right)}}\right)
$$

Bu durum, ortalama $\mathrm{E}\left(\tilde{\mathrm{Z}}_{\mathrm{it}}\right)=\mathrm{k}$ ve $\operatorname{var}\left(\tilde{\mathrm{Z}}_{\mathrm{it}}\right)=2 \mathrm{k}(\mathrm{T}-\mathrm{k}-1) /(\mathrm{T}+1)$ olduğunda geçerli olacaktır (Pesaran ve Yamagata, 2008). 

Bir Analiz

\section{Ek 3. Bootstrap Panel Granger Nedensellik Testine Temel Oluşturan Ön Testlere Ait Sonuçlar}

Yatay Kesit Bağımlılığı ve Heterojenite Test Sonuçları

\begin{tabular}{|c|c|c|c|c|}
\hline \multirow[b]{2}{*}{ Yatay Kesit Bağımlıığı Testleri } & \multicolumn{2}{|c|}{ GSYH-KHARC-KGEL } & \multicolumn{2}{|c|}{ KBGSYH-KHARC-KGEL } \\
\hline & Test İstatistiği & Olasılık Değerleri & Test İstatistiği & Olasılık Değerleri \\
\hline $\mathrm{CD}_{\mathrm{BP}}$ (Breusch and Pagan, 1980) & $1457,294 * * *$ & 0,000 & $1413,906 * * *$ & 0,000 \\
\hline $\mathrm{CD}_{\mathrm{LM}}$ (Pesaran, 2004) & $57,052 * * *$ & 0,000 & $55,034 * * *$ & 0,000 \\
\hline CD (Pesaran, 2004) & $28,094 * * *$ & 0,000 & $26,362 * * *$ & 0,000 \\
\hline $\mathrm{LM}_{\text {adj }}$ (Pesaran et al., 2008) & $71,785 * * *$ & 0,000 & $69,938 * * *$ & 0,000 \\
\hline \multirow{2}{*}{$\begin{array}{l}\text { Homojenite Testleri } \\
\text { (Ho: Eğim katsayıları homojendir) }\end{array}$} & \multicolumn{2}{|c|}{ GSYH-KHARC-KGEL } & \multicolumn{2}{|c|}{ KBGSYH-KHARC-KGEL } \\
\hline & Test Istatistiği & Olasılık Değerleri & Test Istatistiği & Olasılık Değerleri \\
\hline$\Delta$ & $1,784^{* *}$ & 0,037 & $1,744^{* *}$ & 0,041 \\
\hline$\Delta_{\text {adj }}$ & $1,899 * *$ & 0,029 & $1,856 * *$ & 0,032 \\
\hline Ülke Sayısı & \multicolumn{4}{|c|}{22} \\
\hline Ortalama Zaman Dilimi & \multicolumn{4}{|c|}{33 (Dengeli panel veri seti; minimum ve maksimum (Ti): 33 ) } \\
\hline
\end{tabular}

Not: Parantez içerisindeki ifadeler olasılık değerleridir. “***, ${ }^{* *}$ ve *” Yatay kesit bağımsızlığı ve parametrelerin homojenliğini ifade eden sıfır hipotezlerinin “\%1, \%5 ve \%10" seviyelerinde reddedildiğine işaret etmektedir.

Yatay kesit analizlerine dair $C D_{B P} C D_{L M} C D$ ve $L M_{a d j}$ test sonuçları doğrultusunda böyle bir bağımlılığın bulunmadığı yönündeki sıfır hipotezi \%1 anlamlılık seviyesinde adı geçen ülke grupları için reddedilmektedir. Eğim katsayılarının homojenliğine ilişkin $\Delta$ ve $\Delta_{a d j}$ test sonuçlarına göre ise bu katsayıların homojen olduğuna yönelik sıfır hipotezi \%5 anlamlılık seviyesinde her iki bağımlı değişken ile yapılan analize konu ülke grubu için reddedilmektedir. Dolayısıyla, yatay kesit bağımılığının bulunmasının yanı sıra eğim katsayıları heterojendir. Bu durum, Nazlıoğlu vd. (2011: 6618) ileri sürdüğü küreselleşmenin neden olduğu ülkelerarası karşılıklı etkileşimleri doğrular niteliktedir ve aynı gelişme uygulamada karşımıza yatay kesit bağımlılı̆ı olarak çıkmaktadır. 